\title{
Draft Transportation Institutional Plan
}

September 1985

U.S. Department of Energy

Office of Civilian Radioactive Waste Management 


\section{DISCLAIMER}

This report was prepared as an account of work sponsored by an agency of the United States Government. Neither the United States Government nor any agency Thereof, nor any of their employees, makes any warranty, express or implied, or assumes any legal liability or responsibility for the accuracy, completeness, or usefulness of any information, apparatus, product, or process disclosed, or represents that its use would not infringe privately owned rights. Reference herein to any specific commercial product, process, or service by trade name, trademark, manufacturer, or otherwise does not necessarily constitute or imply its endorsement, recommendation, or favoring by the United States Government or any agency thereof. The views and opinions of authors expressed herein do not necessarily state or reflect those of the United States Government or any agency thereof. 


\section{DISCLAIMER}

Portions of this document may be illegible in electronic image products. Images are produced from the best available original document. 
DRAFT TRANSPORTATION INSTITUTIONAL PLAN

September 1985

OFFICE OF STORAGE AND TRANSPORTATION SYSTEMS

OFFICE OF CIVILIAN RADIOACTIVE WASTE MANAGEMENT

U.S. DEPARTMENT OF ENERGY 


\section{SEP 171985}

Dear Reader:

The Office of Civilian Radioactive Waste Management (OCRWM) recognizes two essential tasks in fulfilling its responsiblity for establishing a transportation system to support shipping under provisions of the Nuclear Waste Policy Act of 1982 (NWPA). The first task is to develop the technical and operational capability to support NWPA shipments. Toward that end, the Draft Transportation Business Plan was issued for public comment last month.

The second and equally important task is to establish responsible and effective interactions with those institutions that are affected by NWPA shipping. The program for accomplishing this goal is outlined in the enclosed document, the Draft Transportation Institutional Plan. Earlier internal drafts of the plan have been reviewed and commented on extensively within the Department of Energy/contractor community.

As an active participant in the planning for a transportation system, you are requested to add your comments and suggestions. OCRWM is allowing 90 days for review in order to encourage maximum response. In addition to receiving written comments, OCRWM is sponsoring a Transportation Institutional Workshop in Atlanta on November 19-21, 1985, for the purpose of dialogue and issue discussion. If you have not received prior notice of this meeting and wish to attend, contact Robert Philpott of this office for further details. Both written and oral comments will be carefully considered and, where appropriate, will be reflected in the final plan to be published in the Spring of 1986.

I request that you provide your comments on this document by December 31, 1985. Please submit your comments in writing to:

Mr. Robert E. Philpott

Office of Civilian Radioactive Waste Management

U.S. Department of Energy, RW-33

Forrestal Building

1000 Independence Avenue, S.W. Washington, DC 20585 
Additional copies of the Draft Transportation Institutional plan. can be obtained by telephoning (202) 252-5575, by direct pick-up at the address shown below, or by writing to:

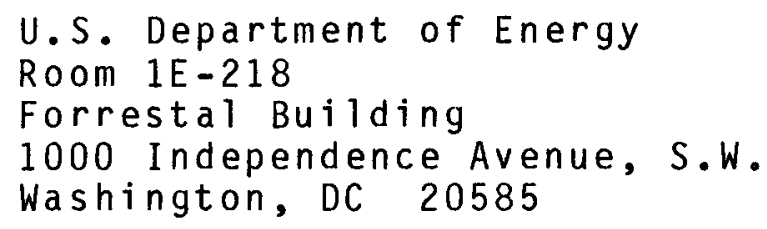

I am also enclosing a framework/description for another document that this office is developing - the Transportation

Institutional Discussion Document. The basis for this document is the series of issue discussion papers that OCRWM initiated last Fall. The nine papers already issued will be reformatted and updated, and discussions of approximately a dozen more issues will be added. OCRWM expects to release the first edition of this document in the Spring of 1986 to coincide with issuance of the final Transportation Institutional Plan.

Thank you for your interest and participation in this important activity.

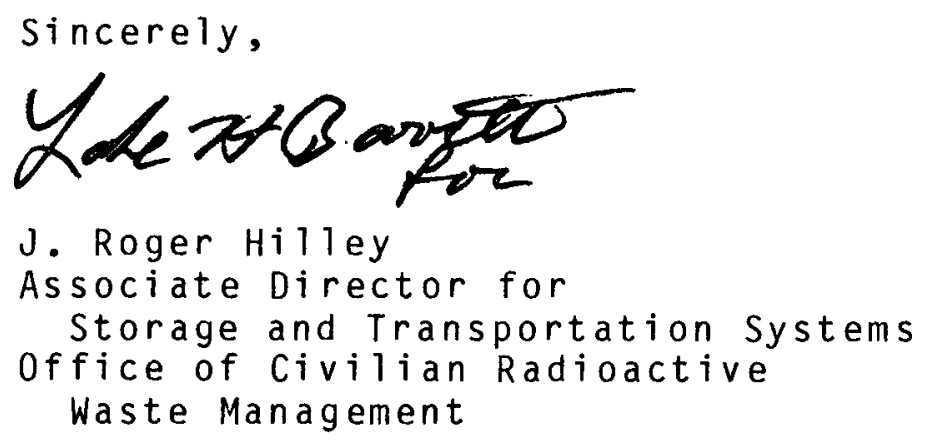

Enclosures 
The Department of Energy (DOE) recognizes that the success of 1 ts program to develop and implement a national system for nuclear waste* management and disposal depends on broad-based public understanding and acceptance. While each program element has its particular sensitivity, the transportation of the waste may potentially affect the greatest number of people, and accordingly is highly visible and potentially issue-laden. Therefore, the office of Civilian Radioactive Waste Management (OCRWM) has developed this Transportation Institutional Plan to lay the foundation for interaction among all interested parties for the purpose of identifying and resolving issues of concern.

The Plan is divided into four chapters. Chapter 1 provides background information and discusses the purpose of the Plan and the policy guidance for establishing the transportation system. Chapter 2 introduces the major participants who must interact to build both the system itself and the consensus philosophy that is essential for effective operations. Chapter 3 suggests mechanisms for interaction that will ensure wide participation in program planning and implementation. And, finally, Chapter 4 suggests a framework for managing and resolving the issues related to development and operation of the transportation system. A list of acronyms and a glossary are included for the reader's conventence. The Plan's appendices provide supporting material to assist the reader in understanding the roles of the involved institutions.

An important supplement to this Plan is the Transportation Issues Discussion Document, which will describe the elements of the transportation issues identified to date and discuss the DOE's plans and options for addressing these issues.** This document, which will be issued periodically for public comment, will evolve in response to programmatic decisions, changing events, and the comments of interested responders. Ultimately, it will record the results of negotiation and consensus-building leading to policy decisions by the DOE or by the agency or organization having jurisdiction over the specific issue.

The scope of this Plan will grow as a network for communication and interaction among interested groups begins to function, as consensus builds, and as program decisions define the details of the system. This Plan will be

* The term "waste" is used here to include both spent fuel from nuclear reactors and the high-level waste resulting from its reprocessing.

**The first edition of the Transportation Issue Discussion Document will be issued in the Spring of 1986 to coincide with publication of the final Transportation Institutional Plan. A framework document explaining format and content is included at the end of this draft plan. 
combined with the Transportation Business Plan*** to provide guidance in the integrated development of the communication network and the hardware and procedures to support shipping under provisions of the Nuclear Waste Policy Act of 1982. Before the system begins operations, a third plan element will be added to delineate operational contacts, requirements, and procedures. The intended goal is to develop a well-concelved, comprehensive plan for the transportation program.

***Draft Transportation Business P1an, DOE/RW-0026, August 1985. 
1 INTRODUCTION . . . . . . . . . . . . . . . . . 1

1.1 Background ........................ 1

1.2 Purpose of the Plan. . . . . . . . . . . . . . . . . 2

1.3 Planning Principles . . . . . . . . . . . . . . . . 2

1.3.1 Safety and Environmental Protection.......... 3

1.3.2 Public Perception and Participation . . . . . . . . 3

1.3.3 Cost Effectiveness. . . . . . . . . . . . . . 3

1.4 Transportation System . . . . . . . . . . . . . . . 4

1.5 Plan Development ................... . 4

2 THE COMMUNICATION NETWORK ................... 7

2.1 Overview . . . . . . . . . . . . . . . . . . 7

2.2 Government ....................... 7

2.2.1 0ther Federal Agencies . . . . . . . . . . 8

2.2.2 State Governments .............. 10

2.2.3 Tribal Governments . . . . . . . . . . . 11

2.2 .4 Local Governments . . . . . . . . . . . . . . 12

2.2.5 Intergovernmental organizations . . . . . . . . . 12

2.3 Utilities and Industry . . . . . . . . . . . . . . 13

2.3.1 Ut1lities..................... 13

2.3 .2 Industry . . . . . . . . . . . . . . 13

2.4 Public . . . . . . . . . . . . . . . . . . 14

3 NETWORK OPERATIONS ..................... . 16

3.1 Overview . . . . . . . . . . . . . . . . . . 16

3.2 Transportation System Development and Related

Institutional Interactions . . . . . . . . . . . . . 17

3.3 Provision of Information . . . . . . . . . . . . . 22

3.3.1 Information Collection. . . . . . . . . . . . . 22

3.3.2 Development of Resources . . . . . . . . . . 23

3.3.3 Information Dissemination . . . . . . . . . 23

3.3.4 Coordination of Activities. . . . . . . . . . . 24

3.4 Support for Network Participation. . . . . . . . . . . 24

3.5 Mitigation of Transportation Impacts . . . . . . . . . 25

4 MANAGING TRANSPORTATION ISSUES. . . . . . . . . . . . . 26

4.1 Issue-Identification . . . . . . . . . . . . . . . . 26

4.1.1 Transportation Meetings, Briefings, and Workshops . . . 26

4.1.2 OCRWM Review of Current Transportation Developments . . 27

4.1.3 Review of Written Comments Submitted to OCRWM . . . . 28 
4.2 Process for Addressing Transportation Issues . . . . . . 28

4.2.1 Transportation Issues Discussion Document . . . . . 28

4.2.2 Transportation Workshops. . . . . . . . . . . 29

4.2.3 Analysis by Representative Organizations . . . . . 29

4.2.4 Cooperation with Other Federal Agencies . . . . . . 30

4.3 Procedures for Resolving Issues. . . . . . . . . . . 30

4.3.1 OCRWM Action. . . . . . . . . . . . . . 30

4.3.2 Cooperation with Other Agencies ......... . 31

List of Acronyms . . . . . . . . . . . . . . . . . . 33

Glossary . . . . . . . . . . . . . . . . . 34

Appendix A - Federal Agency Responsibilities and Applicable Federal

Regulations ................ . A-1

Appendix B - Summary of Procedural Agreements. . . . . . . . . B-1

Appendix C - Directory of Organizational Contacts. . . . . . . . . C-1

(Also included at the end of this draft is the Framework for the

Transportation Issues Discussion Document, the first edition of which will be released as a separate document in the Spring of 1986.) 
Chapter 1

INTRODUCTION

\subsection{Background}

Elghty-six commercial nuclear power plants were in operation in the United States at the beginning of 1985, with some 30 additional ones likely to come on-line in the foreseeable future. These plants have produced spent fuel totaling about 13,000 metric tons of uranium (MTU). By the year 2000, this inventory is expected to rise fivefold, and by 2020 to total approximately $130,000 \mathrm{MTU}$.

Most of this commercial spent fuel is stored in pools at the reactor sites. A small amount has been reprocessed, generating liquid waste that is now stored at a processing site in West Valley, New York. The spent fuel generated in defense programs is routinely reprocessed, and the resulting high-level waste is stored at government sites. Although these wastes can be safely stored on a temporary basis, ultimately they must be solidified (if 1iquid) and isolated from the biosphere in a manner that ensures safe containment for many centuries.

In the course of three decades of international research and development, the technological basis and data have been established to support the design and construction of systems for the safe disposal of these wastes. A consensus has emerged that the most promising approach to permanent waste isolation is disposal in deep geologic repositories. The United States embraced this approach by enacting the Nuclear Waste Policy Act of 1982 (NWPA). The NWPA establishes a program for the siting of two geological repositories and the development of other components of a waste-management system. This system will be financed through fees on nuclear-generated electricity. Primary responsibility for the establishment and operation of a waste-management system is assigned to the Department of Energy (DOE); a new Departmental entity, the Office of Civilian Radioactive Waste Management (OCRWM), was created to manage implementation of NWPA provisions. The NWPA also provides for extensive participation in the waste-management program by States, Indian Tribes, and other interested parties.

Transportation is an integral and essential part of the projected waste management system. Until the capability to transport waste to a repository is successfully established, the disposal of the waste cannot be accomplished. Successful transportation means safe transportation that is not only efficient and economical but is also widely acceptable. To achieve the necessary acceptance, a number of questions and 1ssues regarding the establishment and operation of the transportation system must be resolved. While issue resolution is complicated by the differing--and frequently conflicting--interests of the institutions involved, it is the key to program implementation. Passage of the NWPA provides an encouraging precedent of bipartisan effort and compromise in the interest of national welfare. 


\subsection{Purpose of the Plan}

The purpose of this plan is to define a comprehensive process for identifying, addressing, and resolving the institutional issues related to waste transportation. Such a process will necessarily involve the identification of the interested parties who will participate in, or will be affected by, waste transportation. Moreover, the relationship among these institutions w111 be outlined, and provisions for an interactive network will be established. For purposes of this Plan, institutions have been categorized as (1) governmental (including Federal, State, Tribal, and local governments); (2) utilities and industry; and (3) the public. The Plan further outlines formal mechanisms for the identification of transportation issues and a process for addressing and resolving issues in a responsive, timely manner; the intent is to foster cooperative effort and to focus on communication and negotiation rather than conflict.

\subsection{Planning Principles}

The common goal of the OCRWM and all other parties having an interest in the transportation of radioactive waste should be the development of a safe, secure, efficient, and cost-effective program for the transportation of spent nuclear fuel and high-level radioactive waste to Federal facilities established pursuant to the NWPA. To meet such objectives, the OCRWM has determined that the transportation program, at a minimum, must:

- Meet Department of Transportation (DOT) and Nuclear Regulatory Commission (NRC) safety requirements.

- Encourage public confidence that transportation risks have been reduced to an acceptable level and are not disproportionate to other modern societal risks.

- Establish a process for identifying and resolving transportation institutional issues at the earliest possible time to ensure that such issues do not unnecessarily obstruct activities directed under the NWPA for repository design, licensing, construction, and operation.

- Conduct program activities in such a way as to promote prudent and appropriate expenditure of the Nuclear Waste Fund.

The OCRWM recognizes that planning for the transportation of spent fuel and high-level radioactive waste, and methods of addressing and resolving transportation issues, must be in harmony with Congressional findings and purposes contained in Section 111 of the NWPA. In its implementation of the Act, the OCRWM has identified three major considerations that must be incorporated into all program activities:

- Safety and environmental protection.

- The need for public participation in activities related to the waste management program.

- Cost effectiveness. 
As stated in the NWPA, spent nuclear fuel and high-level radioactive waste create potential risks, and appropriate precautions must be taken to ensure that the waste does not adversely affect public health and safety and the environment. Inherent in planning for the transportation of the waste is the need for the OCRWM to identify those factors that will affect the safety and security of transportation and to establish criteria that may be used to determine which risk factors can and should be mitigated. In addition, areas of uncertainty with regard to the risks of transportation must be identified, and plans must be developed for reducing such uncertainty.

When engaged in future activities related to the transportation of commercial waste to NWPA facilities, the OCRWM will meet all existing DOT and NRC safety and security standards. In addition, a major program of quality assurance w111 be integrated into all programmatic activities related to the development and operation of the NWPA transportation system.

\subsubsection{Public Perception and Participation}

The NWPA recognizes that spent fuel and high-level waste have become subjects of public concern, and that state and public particlpation in the planning and development of the waste management program is essential to promote better understanding and to foster public confidence in the safety of waste disposal. In keeping with this Congressional finding, the OCRWM recognizes that expressions of public concern must be substantively addressed. To meet the responsibility for addressing the transportation of the waste, the OCRWM w11l work actively with the States, Indian tribes and other interested parties throughout the planning process to ensure that transportation safety and cost factors are identified, evaluated, and adequately incorporated into program decisions.

\subsubsection{Cost Effectiveness}

The NWPA requires that the costs of radioactive waste disposal be borne by the owners and generators of such waste, and provides for the establishment of a Nuclear Waste Fund for this purpose. As noted in the Mission Plan*, the OCRWM recognizes its responsibility to undertake program activities financed by the Nuclear Waste Fund in an efficient and cost-effective manner. In directing those activities necessary for the development and implementation of the NWPA transportation system, OCRWM further recognizes the need to identify categories of transportation costs that should properly be covered by the Nuclear Waste Fund. Similarly, OCRWM will identify those costs that should be covered by other sources.

*Mission Plan for the Civilian Radioactive Waste Management Program, $\mathrm{DOE} / \mathrm{RW}-0005$, June 1985 . 
In implementing the DOE's mandate under the NWPA, the OCRWM wIII develop and operate a transportation system to move waste from the commercial reactors, where it is generated and currently stored, to the repositories for disposal*. This system requires development of the physical equipment (hardware) and transportation services to transport the waste as well as an institutional framework that allows OCRWM to move forward in developing and operating the system.

The physical transportation system will consist of shipping casks, carriage equipment, and associated ancillary equipment. The services required will include carriage of the fuel by commercial transport companies, maintenance of the casks and other equipment, and training of system operators. In accordance with the NWPA, the Secretary "sha11 utilize by contract private industry to the fullest extent possible" to develop and operate this system.

Two waste-management system strategles are described in the Mission Plan: the Authorized System, as defined by the NWPA, and the Improved-Performance System. Under the former strategy, waste would be transported from the point of origin (principally from commercial reactors) to a repository. Consolidation of waste and packaging for disposal would occur at the repository, which would begin operations in 1998. In addition, limited Federal interim storage of waste would be provided if necessary. The DOE is further directed to enter into cooperative programs with utilities to demonstrate the dry storage of spent fuel to enhance at-reactor storage capability.

Under the Improved-Performance System strategy, waste would move from reactors by truck, train, or barge to a monitored retrievable storage (MRS) facility where it would be consolidated and packaged for disposal and, if necessary, temporarily stored. Movement from the MRS facility to repositories would be primarily by train. The DOE would take title to the waste at the reactors and begin operating the transportation system in 1996. In January 1986, the DOE w11l forward a proposal for an MRS facility to Congress for consideration and approval.

\subsection{Plan Development}

The Transportation Institutional Plan is being developed through a process of public review and comment. Response to this draft document will be considered and reflected in a final version in the Spring of 1986. Discussion papers on transportation issues are being developed on a parallel track and

*Under provisions of the NWPA, the President evaluates the use of the repositories developed under the Act for the disposal of the high-level waste resulting from atomic energy defense activities. Such an evaluation has been made, and, in April 1985, the President directed the Secretary of Energy to proceed with plans and actions to dispose of defense waste in a commercial waste repository. Arrangements, including the procedures under which such waste will be transported, are to be decided. 
w111 be included in a supplementary document, the Transportation Issues iscussion Document. The first edition of that publication will also be issued in the Spring of 1986, with annual reissuance thereafter.

The Transportation Institutional Plan supplements the transportation information provided in the OCRWM Mission Plan, and is complementary to the Transportation Business Plan. It is consistent with the prospective overall OCRWM Institutional Plan in policy and program implementation and interaction. Furthermore, it meets the planning requirements specified in the OCRWM Program Management System Manual.

As noted in the Preface, it is intended that the Institutional Plan and the Business Plan will eventually be combined into a single, integrated document. As the transportation system develops, an operations plan detailing how the system will function will be added. The goal is to provide a comprehensive Transportation Plan offering information and guidance to all who will participate in and be affected by the transportation of spent fuel and high-level radioactive waste. The evolution of the comprehensive Transportation Plan is portrayed in Figure 1. 


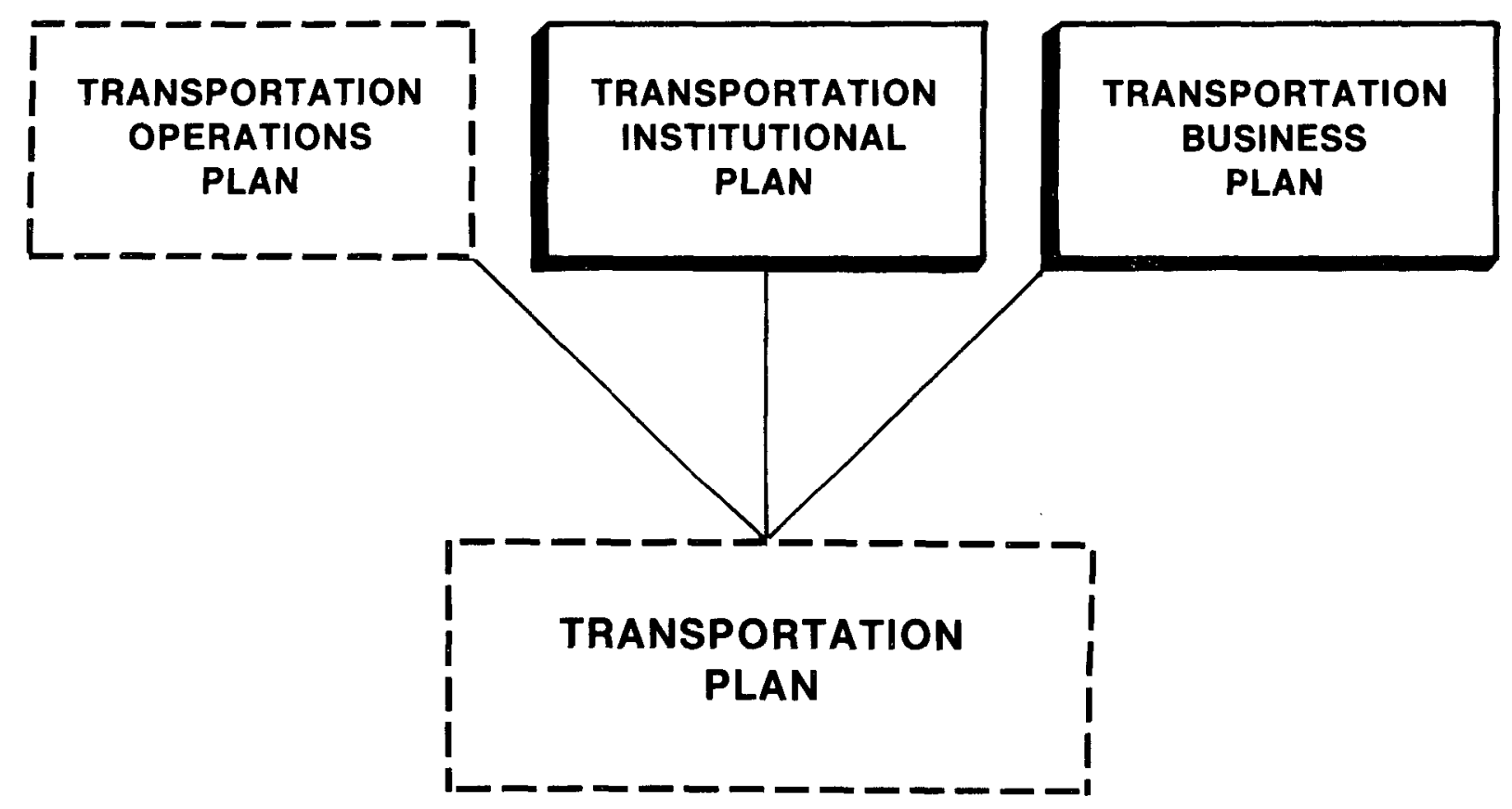

AVAILABLE DRAFT DOCUMENT

$----\infty$ PROJECTED DOCUMENT

Figure 1. Evolution of the transportation plan. 
This chapter discusses the establishment and maintenance of the communication network for the transportation system mandated by the Nuclear Waste Policy Act. The discussion centers on the institutions involved in this network and their interactions in the transportation program of OCRWM.

\subsection{Overview}

The OCRWM is committed to addressing and resolving concerns over nuclear waste transportation expressed by Federal, State, Tribal, and local officials; utilities and industries; and the public. This Plan is being developed to clearly state the princlple of resolving these concerns through a consistent form of interaction. The communication network provides a means of discussion, information exchange, and negotiation regarding the concerns of the institutions.

The institutions that share an interest in the transportation system for nuclear waste have differing roles and responsibilities. The OCRWM recognizes the importance of developing communication with each group concerned in order to more fully understand these differences. The purposes of this Plan, as stated in the previous chapter, are:

- The establishment and maintenance of a communication network.

- The development of mechanisms to assist in identification and resolution of institutional concerns.

For purposes of this Plan, institutions are categorized as (1) governmental, Including Federal, State, Tribal, and local; (2) utilities and industry; and (3) the public. Each category is addressed, respectively, in the following sections of this chapter.

\subsection{Government}

The Nuclear Waste Policy Act of 1982 assigned to the DOE primary responsibility for the development and operation of a national system for the management and disposal of spent fuel and high-level radioactive waste and created the Office of Civilian Radioactive Waste Management (OCRWM) to carry out the associated program functions. Certain provisions of the NWPA direct and control transportation strategy. These provisions require the DOE to:

- Accept commercial spent fuel at the reactor site or point of origin.

- Use the private sector "to the maximum extent possible" in establishing and operating the transportation system.

- Seek to enter into written consultation and cooperation agreements with potential repository host States and affected Indian tribes. 
Further, when shipping commerclal waste to facilities developed under the NWPA, the DOE has made the commitment to comply with DOT and NRC regulatory requirements that pertain to the transportation of nuclear materials.

The OCRWM organization is 11lustrated in Figure 2. The Office of Storage and Transportation Systems (OSTS) is responsible for transportation activities of the program, which include the development of the Transportation Business Plan, this Plan, and, ultimately, the comprehensive Transportation Plan that will include the business, institutional, and operational elements for the NWPA transportation system. The principal objective of the OSTS is to ensure that transportation activities are performed in a safe, secure, and cost-effective manner, in accordance with all laws and regulations, and in a way that contributes toward a full public understanding and acceptance of programs, goals, and activities.

A DOE Operations office will be designated as the lead support organization for OCRWM institutional activities related to transportation. A primary responsibility of the operations office will be to manage the projects related to addressing and resolving transportation issues.

The DOE transportation programs for shipping non-commercial nuclear materials are centrallzed under the direction of the Assistant Secretary for Defense Programs. This existing transportation system provides a source of expertise for operations, policy and procedures, cask certification, and research and development. While the two programs will have differing missions and requirements, the OCRWM has been working closely with the Defense Programs office towards the goal of integrating certain program elements (e.g., safety and research and development).

OCRWM interactions with other Federal agencies, State governments, local governments, Indian Tribal governments, and intergovernmental organizations are briefly described below.

\subsubsection{Other Federal Agencies}

The implementation of the transportation system depends on the successful coordination of the transportation activities with appropriate Federal agencies and conscientious compliance with the pertinent regulations and orders promulgated by these agencies. Because of the Federal responsibility to protect the general welfare of cltizens, hazardous waste transportation--and particularly radioactive waste transportation--is intensely regulated. The DOE, the NRC, and the DOT are the major Federal agencies involved in the transportation of radioactive materials; however, the actions of other Federal agencies may affect transportation. The OCRWM will interact on a regular basis with the NRC, the DOT, the Federal Emergency Management Agency (FEMA), and others as appropriate. The purpose of these interactions is to cooperate with these agencies and to ensure that all applicable regulatory requirements are met.

Interdepartmental interactions may be guided by Memoranda of Understanding (MOU) or other formal agreements between or among the affected Federal agencles. In 1979, the DOT and the NRC entered into an MOU to outline their respective areas of primary regulatory jurisdiction over the transportation of commercial radioactive materials. Briefly, the DOT is responsible for regulating safety in the transportation of all hazardous 


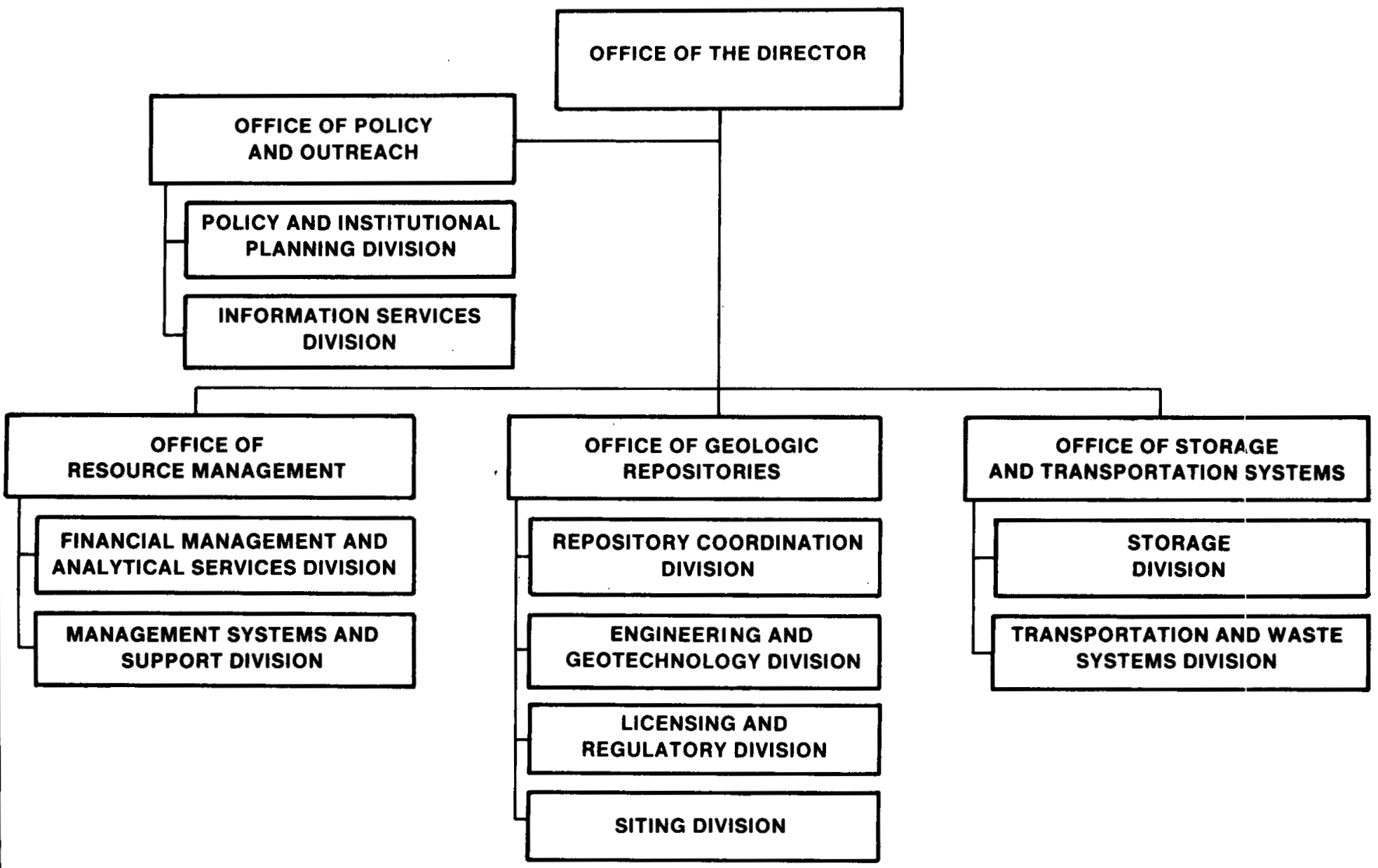

Figure 2. The Office of Civilian Radioactive Waste Management. 
materials. Safeguard aspects, such as the recelpt, possession, use, and transfer of high-level radioactive waste and spent fuel by NRC 1icensees, are regulated by the NRC. The NRC is also responsible for the regulation of the packaging that is used by NRC-1icensees to transport spent nuclear fuel.

A procedural agreement between the DOE and the NRC on packaging certification has been established. In addition, an MOU has been developed between the DOE and the DOT that relates to the exchange of information. The OCRWM may also informally interact with other Federal agencies regarding technical information exchange, operations planning, and institutional concerns.

Appendix A reviews the statutory roles and responsibilities of the major Federal agencles with whom the DOE and the OCRWM will interact. Appendix B summarizes the agreements under which the interactions are conducted.

\subsubsection{State Governments}

The OCRWM has the responsibility under the NWPA to endeavor to establish consultation and cooperation agreements with potential host repository states and affected Indian Tribes. At present, 23 States are involved in the siting programs for the first repository (sites in basalt, tuff, and salt) and for the second repository (sites in granite [crystalline rock]). Grouped by repository host rock, these states are as follows:

- Basalt: Washington

- Tuff: Nevada

- Salt: Texas, Utah, Louisiana, and Mississippi

- Granite: Connecticut, Georgla, Maine, Maryland, Massachusetts, Michigan, Minnesota, New Hampshire, New Jersey, New York, North Carolina, Pennsylvania, Rhode Island, South Carolina, Virginia, Vermont, and Wisconsin

These are the only States under consideration for either the first or the second repository. The OCRWM has established contacts with these States, and the States have, in turn, appointed or designated key representative offices (see Appendix C).

With respect to the monitored retrievable storage (MRS) program, the OCRWM is working closely with officials of the State of Tennessee where three potential sites have been identified. Interaction at this stage centers chiefly on provision of information to support State and local evaluation of and participation in OCRWM planning. Should Congress approve an MRS facility as proposed by the DOE, interaction with Tennessee States will become more focused.

Although the NWPA did not address interactions with States not directly affected by repository siting programs, it is the intent of the OCRWM to interact with all States through whose jurisdictions NWPA shipments will transit. Through the Secretary of Energy's Office, the OCRWM w111 ask the governors of these non-repository States to designate one focal point, 
individual, or State council within the State to act as a liaison with the : 'OCRWM on transportation matters. The representative could communicate directly with the OCRWM to provide information on State concerns and issues and to keep State officials informed on OCRWM programmatic matters. In some instances, the OCRWM will also seek direct contact with individuals having specialized transportation expertise within the State governments.

The OCRWM will work with the States through the communication network to develop a transportation system that engenders confidence that the public health and safety will be protected. In pursuit of this objective, States will be provided early access to planning procedures regarding waste transportation to a repository. The areas of major concern to the States will be addressed and ample opportunity will be allowed for the States to identify issues and to communicate with the OCRWM. In this manner, the OCRWM hopes to eliminate or lessen the underlying concerns of State and local authorities that may have led to enactment of laws and ordinances which restrict the transportation of nuclear materials through their jurisdictions. The OCRWM will work with both the executive and legislative branches of State governments in ensuring that their concerns are considered in program plans and decisions.

\subsubsection{Tribal Governments}

Indian Tribes (Nations) occupy a position in the Federal structure similar to, but distinct from, State governments. The NWPA acknowledges the sovereign status of Indian Tribes. The U.S. Supreme Court upholds the legal and policy concepts of inherent Indian sovereignty and Indian governmental authorities. In 1832, the Supreme Court stated:

...the several Indian nations [are] distinct political communities, having territorial boundaries, within which their authority is exclusive, and having a right to all the lands within those boundaries, which is not only acknowledged, but guaranteed by the United States... Indian nations had always been considered as distinct, independent political communities, retaining their original rights, as the undisputed possessors of the soil from time immemorial. Worcester v. Georgia, 31 U.S. 515, 558 (1832).

The term "government-to-government relations" is used to describe the relationship of Indian Nations and the Federal government as two distinct governmental entities. President Reagan, in the White House Indian Policy Statement of January 1983, reaffirmed the "government-to-government" policy. Among other actions described in the policy statement, the President moved the White House liaison for Federally-recognized tribes from the office of Public Liaison to the Office of Intergovernmental Affairs, which maintains liaison with State and local governments.

The NWPA specifically intended that affected Indian tribes, along with the States potentially affected by the repository site selection, be involved in the planning process. The NWPA states that the Secretary of Energy must seek to enter into written Consultation and Cooperation agreements with the governing body of an affected Indian Tribe. This agreement serves as a negotiating instrument, initiating an official means of dialogue between DOE and the Tribe during preliminary and final site selection, and may include a 
financial assistance agreement. To date three Tribes--the Yakima Tribe, the Nez Perce Tribe, and the Umatilla Tribe-have been identified as having

"affected" status. While the NWPA does not prescribe interactions with other than affected Indian Tribes, the OCRWM will seek to work with all interested Indian Tribes through whose jurisdictions NWPA shipments will pass. (See Appendix C for existing contacts.)

In working with the Indian Tribes, the OCRWM expects that there may be some considerations that are unique. The OCRWM is committed to maintaining an open and continuing dialogue to ensure that Tribal interests are fully represented and considered.

\subsubsection{Local Governments}

The transportation of radioactive waste to facilities developed under the NWPA will affect communities throughout the nation. The OCRWM is committed to establishing and maintaining effective relations with local governments and will ensure that community and local officials are provided with accurate and understandable transportation information. In turn, the OCRWM recognizes that local officials are uniquely qualified to provide information on transportation conditions and impacts within their areas of jurisdiction and, accordingly, are important participants in developing procedures for the transportation system. In planning for safe and secure shipping operations and emergency response capability, the OCRWM will work with local fire, police, and emergency services who have primary responsibility for responding to transportation accidents and other emergencies involving radioactive materials.

The OCRWM will interact with local governments both through designated State liaison representatives and directly, as particular transportation issues or situations indicate. Direct contact will be through workshops, public meetings, and responses to written requests.

\subsubsection{Intergovernmental Organizations}

Intergovernmental organizations may include State, Tribal or local officials with the same or similar responsibilities. While not a substitute for direct contact with the State, Tribal or local governments, working with such groups has the benefit of reaching significantly larger constituencies than would otherwise be possible.

Four of the State-related associations having an existing network dealing with waste management issues are the National Governors' Association, the National Conference of State Legislatures, the Southern States Energy Board, and the Western Interstate Energy Board. These organizations have developed committees that work specifically on waste-management or waste-transportation issues. Two Indian Tribal organizations having an interest in waste transportation are the National Congress of American Indians and the Council of Energy Resource Tribes. Through such established networks to the States and Tribes, the OCRWM has been able to solicit and obtain views and to participate in forums for discussion and information exchange. 
Additional participation from existing networks is being solicited. Organizations representing local governments, such as the League of Cities and the Conference of Mayors, and national associations of State technical and professional personnel will be contacted by the OCRWM to establish their network role with regard to waste transportation.

\subsection{Utilities and Industry}

The NWPA programs will involve close llaison with the nuclear power utilities and with many elements of the nuclear materials transportation Industry. In November 1984, the OCRWM published the Transportation Business Plan: Strategy Options Document to initiate dialogue with the utilities and industry for understanding of and cooperation in future commercial-waste transportation activities and operations. The recently released Draft

Transportation Business Plan provides information on contracting procedures, equipment requirements, facility requirements, funding availability, and other business activities. The interrelationship of the technical and institutional activities is fostered by the communication network that links the utilities and industry with the OCRWM and the other institutions.

The purpose of the interactions between the OCRWM and the business sector is (1) to achieve the goals and objectives of the transportation program by implementing a safe and efficient waste transportation system; (2) to understand and resolve business concerns related to transportation; (3) to keep industry apprised of programmatic, technical, and regulatory developments; (4) to work closely with the utilities and industry to resolve the concerns ralsed by State, Tribal, and local governments and to achieve an atmosphere of public trust and confidence; and (5) to solicit the cooperation of the utilities in establishing and maintaining public information programs in their service areas.

\subsubsection{Utilities}

As generators of spent fuel and as the group responsible for most of the payments to the Nuclear Waste Fund, utilities have a vital interest in safe, efficient, and reliable waste transportation. As agents of the rate-paying consumers of nuclear-generated electricity, utilities are responsible for encouraging cost-effective use of the Nuclear Waste Fund. They have a strong interest in most of the activities associated with developing and operating the waste transportation system, including the OCRWM's schedules for receiving the fuel; developing dual-purpose casks; planning for transportation operations; establishing cask-handling procedures; integrating transportation service with existing facilities at the plant site; and coordinating with State, Tribal and local transportation interests, particularly in the vicinity of the plant site.

\subsubsection{Industry}

The NWPA directs the DOE to "utilize private industry to the fullest extent possible in each aspect of such transportation" (Section 137(a)(2) of NWPA). In effect, selected contractors will be responsible for completing all tasks needed to design and manufacture the required shipping casks and to ship the waste from generators to storage or disposal locations. Two major industry elements will be involved: (1) cask designers and manufacturers; and (2) carriers and transportation service contractors. 
Primary functions of cask designers and manufactures will include cask design and engineering, certification and testing, prototype fabrication, and cask fleet fabrication. Interest from this group centers on the OCRWM's role in cask development and procurement, public input to cask design criteria, cask certification requirements, cask prototype fabrication, cask testing, cask procurement, dual-purpose casks, and the use of existing casks.

Service contractor functions will include procurement of casks for a transport fleet, carriage agreements, maintenance of equipment, inspection of equipment and operations, and training of all operating personnel. The draft Transportation Business Plan specifies that the OCRWM w11l develop a11 service guidelines and specifications that will be implemented by its contractors. OCRWM will consider the possibility of regional service contractors as compared to the use of a single national comprehensive service contractor or multiple individual contractors.

The OCRWM will require that operational safety training will be conducted by service contractors following OCRWM-established standards. Through an extensive quality assurance/quality control program, the OCRWM will verify compliance with training requirements. The OCRWM will also address program needs regarding the training of drivers, maintenance and service mechanics, inspectors, and security personnel.

The Transportation Business Plan and Section 3.2 of this document w111 describe more precisely the interactions between the OCRWM and its industry contractors.

Representative organizations such as transport associations, trade representatives, labor groups, and utility associations will also be solicited for participation in the transportation network. Appendix C lists a number of these groups.

\subsection{Public}

Success of the transportation component of the waste-management program depends in great part on the development of public confidence and understanding. While much can be accomplished by means of open dialogue with State and Tribal governments through the designated State and Tribal liaison representatives and with State technical agencies, the OCRWM recognizes the importance of interaction with members of the interested public.

Specialized segments of the public with whom the OCRWM will interact are groups in the technical community, such as the National Academy of Sciences. Members of such organizations will be asked to serve as peer review groups to evaluate OCRWM technical work and analyses. The expertise and independent status of these groups makes them particularly credible as reviewers and spokesmen.

Interaction with members of the media will be in accordance with current OCRWM policy and will normally be handled by the OCRWM's Press officer. To ensure transmission of accurate information to media audiences, the OCRWM will establish media information programs and provide opportunities for media observance of program activities. 
The OCRWM welcomes participation in its outreach program by public

* interest groups known to have an interest in the waste management

transportation program. Examples of these organizations are environmental groups or public safety groups who might wish to recelve program information or comment on program activity. Organizations may indicate their interest in participating by corresponding directly with OCRWM. (A partial listing of groups is included in Appendix C.)

The OCRWM also recognizes the importance of listening and responding to the concerns of individual citizens. The information resources to be made available for public interactions are described in Chapter 3. 
NETWORK OPERATIONS

\subsection{Overview}

The function of the communication network is to provide a two-way flow of information and understanding between the OCRWM and institutions. This plan and the establishment of the network operations emphasize the commitment of the OCRWM to work with institutions to address and resolve issues. The objective is to establish a safe, efficient, cost effective and publicly acceptable transportation system. Four guidelines for fostering a smoothly functioning network are described below.

- Listening to and Understanding the Concerns of Institutions.

Designated DOE staff from both the OCRWM and Operations Offices will communicate and listen to the interests expressed by the various institutions. Should a concern be identified, efforts will be employed to address the concern and work toward resolution. Where issues have not yet been identified, contact will be maintained so as to ensure avenues for identification and resolution of concerns or issues that might subsequently arise. The means of resolution of institutional concerns may vary according to the issue at hand.

Inherent in achieving understanding of the issue is assurance that language and terminology is uniformly understood by all parties. Accordingly, the OCRWM must clearly define all technical terms and eliminate, where possible, specialized jargon.

- Responding to Identified Concerns.

The OCRWM will respond to institutional concerns raised during the communication with the network through personal contact, meetings, public hearings, or correspondence. Continuing dialogue between the OCRWM and the institutions will allow for clarification of each participant's position. The process of developing issue-discussion papers, which has been initiated by the OCRWM and is more fully described in Chapter 4, is an example of how the OCRWM will present its position and solicit reaction from the institutions.

- Keeping Institutions Informed Through Dissemination of Program Information.

The OCRWM recognizes the Importance of providing adequate, timely information to network participants to avoid the possibility of miscommunication that could lead to adversarial positions over particular issues. 
The purpose of information development and dissemination is twofold:

1. To foster meaningful dialogue by providing those who interact with the DOE routinely with factual informational materials for network membership use and for their constituents.

2. To inform and involve the public in as many aspects of the program as possible; to improve public conceptions on the safety of nuclear material transportation; and to provide ready, consistent responses to general inquiries. Section 3.3 of this chapter discusses development and dissemination of information.

- Resolving Institutional Concerns.

Issues may be the result of recurrent concerns that have not been resolved to the originator's satisfaction. Communication may become difficult if both parties have developed adversarial positions. It is therefore important that, as a first step in discussing the issue, the underlying motives to positions taken on the issue are understood. This determination can only be accomplished if the communication network is functioning. The network will normally operate through personal contacts, workshops, public hearings, correspondence, and information dissemination. Early identification of potential problem areas will provide all parties with timely notice of pending issues. Issue identification and resolution are discussed in Chapter 4.

3.2 Transportation System Development and Related Institutional Interactions

To foster a coordinated, effective transportation program, institutional interaction activities should be synchronized with the technical development of the transportation system. As described in the Draft Transportation Business Plan, technical development or acquisition of the system has two main phases: cask development and transportation operations. The first phase is divided into three cask development initiatives: from-reactor-to-repository casks; from-MRS-to-repository casks (subject to Congressional approval); and nonstandard spent fuel and component casks.

The second phase, transportation operations, is delineated by two contractor categories: service contractors; and independent overview, inspection, and quality assurance contractors. Operational activities during this phase include the procurement of a fleet of casks, carriage arrangements, maintenance of equipment, inspection of equipment, operations, and training of all operating personnel.

The summary schedule for acquisition of the transportation system is shown in Figure 3. The relationship between technical activities and the probable institutional activities and information resources is depicted in Table 1 for four time frames (1985-86; 1987-91; 1992-96; and 1996 through Program end.

The OCRWM is currently defining the requirements for the overall transportation system in terms of needs, capabilities, schedules, costs, and operating constraints. The major institutional activities are development of the network contacts, interaction with other Federal agencies and with 


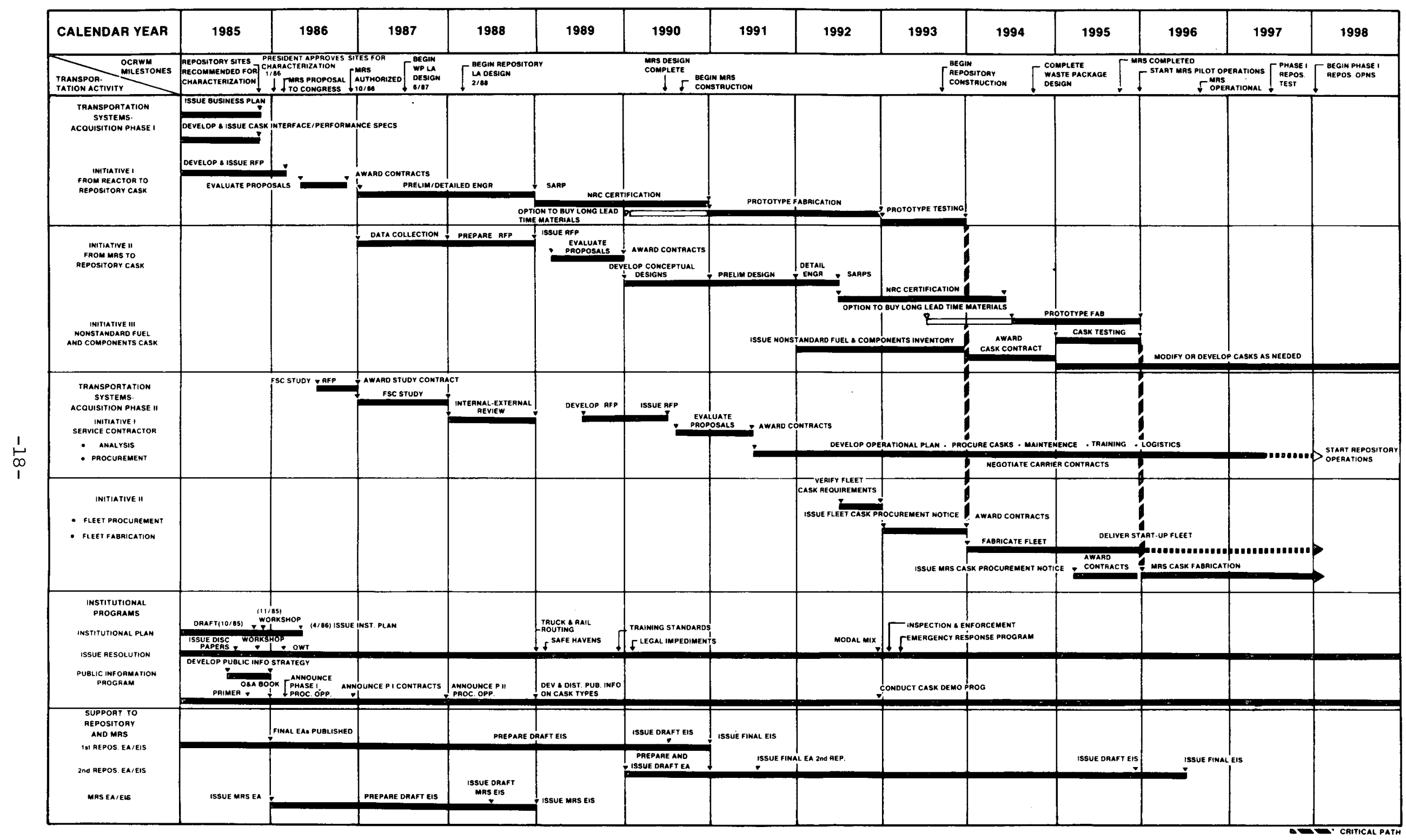

* INITIATIVE II WILL COMMENCE IF THE MRS IS APPROVED BY CONGRESS

Figure 3. Transportation program schedule 


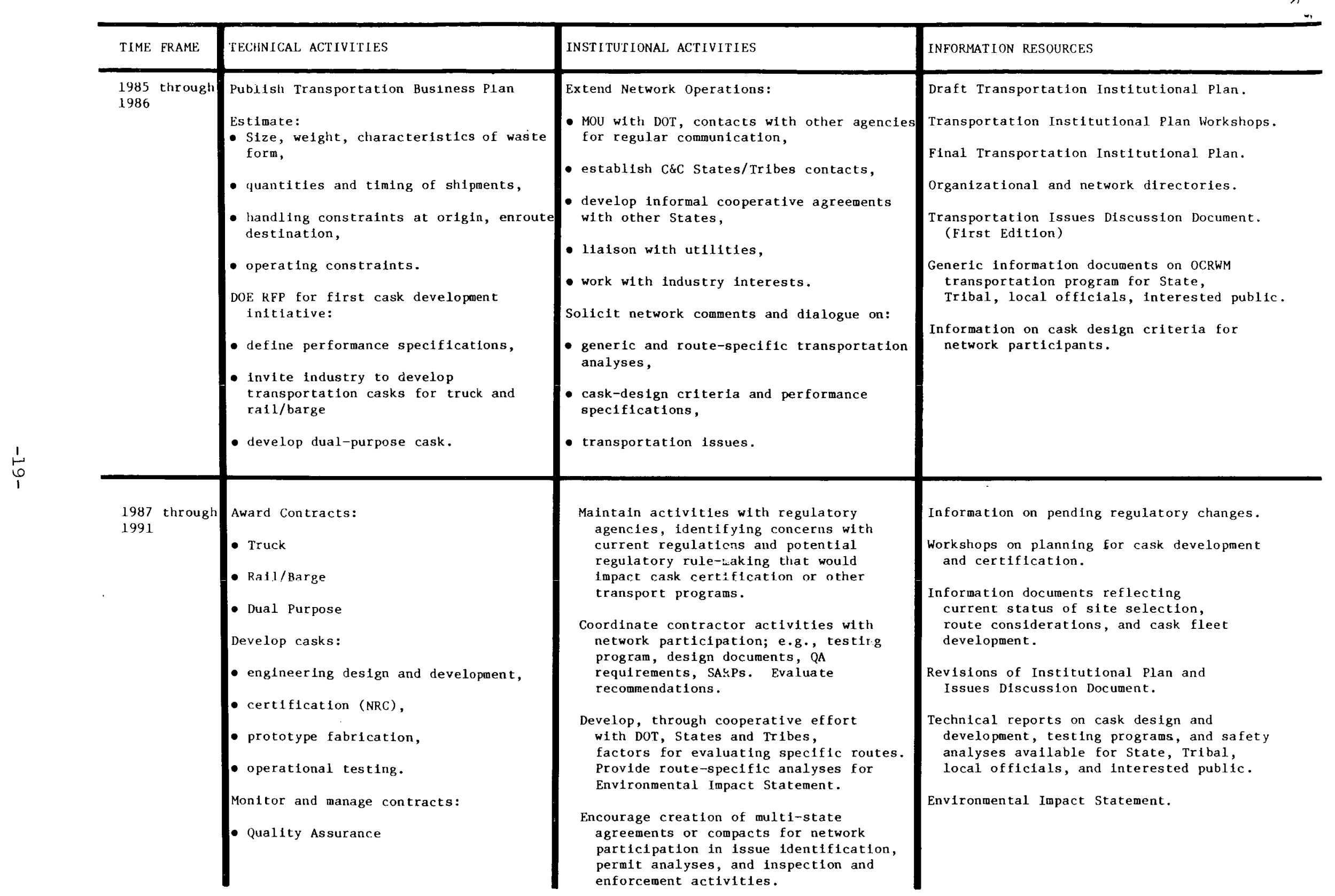

Table 1. Relationship between technical development and institutional planning. 


\begin{tabular}{|c|c|c|c|}
\hline TIME FRAME: & TECHNICAL ACTIVITLES & INSTITUTIONAL ACTIVITIES & INFORMAT ION RFSOURCES \\
\hline $\begin{array}{l}1992 \text { through } \\
1996\end{array}$ & $\begin{array}{l}\text { Fabrication of casks. } \\
\text { Develop training programs for } \\
\text { operating personnel. } \\
\text { operation of prototype units. } \\
\text { Issue RFP for services for fleet } \\
\text { operations: } \\
\text { - Assemble fleet: } \\
\text { - casks } \\
\text { - vehicles } \\
\text { - Train: } \\
\text { - operators } \\
\text { - inspectors } \\
\text { - maintenance } \\
\text { - securlty } \\
\text { - Provide logistical support } \\
\text { - Arrange and manage traffic. }\end{array}$ & $\begin{array}{l}\text { Provide assistance and support for } \\
\text { elnergency-response planning and } \\
\text { tralning. } \\
\text { Develop operational plan that defines: } \\
\text { - transportation mode and State- } \\
\text { preferred routes, } \\
\text { - shipment frequency, } \\
\text { - defense-waste parameters, } \\
\text { - inspection and enforcement activities, } \\
\text { - Incident reporting. } \\
\text { Work with network to address local } \\
\text { 1ssues related to site selection } \\
\text { and route-speciffic selectlon. } \\
\text { Participation by local governments, } \\
\text { utilities, States, Tribes, and } \\
\text { under regional compacts. } \\
\text { Continual evaluation of regulatory } \\
\text { concerns: coordinate with network } \\
\text { on State and local ordinances, } \\
\text { permits and fees, cooperative } \\
\text { efforts for inspection and enforcement. } \\
\text { Update Issues Discussion } \\
\text { Document. } \\
\text { Utilities involved in trainlng } \\
\text { for operating personnel } \\
\text { (facility operat fons). }\end{array}$ & $\begin{array}{l}\text { Cask prototype demonstrations for public. } \\
\text { Workshops on operational plan } \\
\text { for network partictpants. } \\
\text { Operational plan for support services. } \\
\text { Revisions of Transportation Institutional } \\
\text { Plan and Issues Discussion Document. } \\
\text { Training materials for operating } \\
\text { personnel made avallable for } \\
\text { State, Tribal, local officlals, } \\
\text { and interested public. } \\
\text { Route-specific pubilc information forums } \\
\text { (utility participation). } \\
\text { Public information programs that include: } \\
\text { - route-specific detatls, } \\
\text { - cask-demonstrations, } \\
\text { - cost/risk analyses using } \\
\text { route-specific detail } \\
\text { constraints, } \\
\text { - safety/environmental } \\
\text { analyses using route- } \\
\text { specific constraints. }\end{array}$ \\
\hline $\begin{array}{l}1996 \text { through } \\
\text { Program End }\end{array}$ & $\begin{array}{l}\text { Direct all phases of shipment } \\
\text { operation: } \\
\text { - procurenent, } \\
\text { - personnel training, } \\
\text { - maintenance, } \\
\text { - transport operations, } \\
\text { - traffic management. } \\
\text { Future developinent and } \\
\text { improvement studies. }\end{array}$ & $\begin{array}{l}\text { Maintenance of network contacts, } \\
\text { issue identification, regulatory } \\
\text { evaluation, review of operations } \\
\text { plan and update, planned improv- } \\
\text { ments, and new developments. } \\
\text { Conduct of Federal/state inspection } \\
\text { program. }\end{array}$ & $\begin{array}{l}\text { Continued pubilc information } \\
\text { programs with utility } \\
\text { particlpation 1n localized } \\
\text { route-specific forums. } \\
\text { Workshops for network partici- } \\
\text { pants on new developments. }\end{array}$ \\
\hline
\end{tabular}

Table 1.(cont.) Relationship between technical development and institutional planning. 
business interests, and planning and initiation of public information activities. The network will participate through written comments in (1) the evaluation of the cask (reactor-to-repository) design criteria and performance specifications prior to the solicitation of cask design concepts from industry and (2) the identification of transportation issues and determination of resolution mechanisms.

In early 1986, the OCRWM w1ll invite industry proposals for the engineering design and development, prototype fabrication, testing, and certification of reactor-to-repository casks.* At least two casks of each modal type (truck and train/barge) will be selected for engineering development and certification. Contracts will be awarded on the basis of the best combination of cost, schedule, and technical features. Institutional activities during this phase will be intensive. The OCRWM will consult with regulatory agencies and advise the utilities and industry on potential changes to the regulations that could affect cask development. The OCRWM will work closely with contractors and will provide the network with information on the development of testing programs, quality assurance requirements, and safety analysis reports for certification. The OCRWM will encourage the development of multi-State agreements or compacts for coordination of inspection and enforcement, emergency planning, and other activities related to transportation safety.

The main thrust of the procurement for operational services will begin in 1990 when the request for proposals from the service contractors will be issued. Training programs for operating personnel will be developed. Design parameters of prototype casks will facilitate planning for preferred modes of transportation, frequency of shipments, and other operational parameters. Post-1990 institutional interactions during this timeframe will be directed towards the more site-specific and route-specific concerns of the potentlally affected institutions. The OCRWM will provide assistance and support for emergency-response planning and training, address local issues, and evaluate training programs for operating personnel. Operating procedures will be fully defined, and an operations plan will be developed for inclusion as the third element of the comprehensive Transportation Plan.

As transportation operations begin, all elements of the communication network will be fully developed and network interactions will be extensive. The OCRWM will comply with DOT and NRC transportation regulations and will cooperate with the Federal regulatory agencies and the States in comprehensive inspection programs. In addition to quality assurance and quality control of industry services, the OCRWM will work with the utilities and industry to plan for future development and improvement of the transportation system. Finally, a strong program of public information and interaction will be conducted to keep interested citizens fully informed of program activity.

*It is projected that a request for proposals for the second cask development initiatives will be issued one year after Congressional approval of an MRS facility; a request for proposals for the third cask development initiative is expected to be issued in the mid-1990s. 


\subsection{Provision of Information}

The provision of transportation information that is accurate, objective, and current is a basic ingredient of public understanding and acceptance of waste-management goals. Accordingly, the OCRWM plans a program to develop the necessary informational resources and to establish the mechanisms and procedures through which the information will be disseminated. The successful implementation of this program will foster a network that is knowledgeable and capable of participation in waste transportation planning.

\subsubsection{Information Collection}

Prior to the development and dissemination of informational resources, several requirements are necessary to determine activities. These requirements include:

- Identifying and anticipating institutional interests and concerns that require provision of information.

- Identifying Intended audiences.

- Identifying existing Informational material that can be of use with minor updating and revision.

- Determining what resources need to be developed and their order of priority.

To support fulfillment of these requirements, the OCRWM plans to collect and analyze information on a wide range of transportation subjects and interests. The resulting information base will provide the raw materials for resource development.

Major categories of public interest (defined to date) for which informational resources are required include the following:

- Background information such as the history of nuclear activities and general explanations of nuclear technology and the effects of radiation.

- Information on other OCRWM programs that will affect transportation, such as facility descriptions and waste-acceptance schedules.

- Transportation information (both generic and OCRWM-program-specific) such as the regulations that govern waste shipments; identification of responsibilities (shipper, carrier, regulator, cask developer etc.); cask development and testing; and risk analyses.

These categories will be defined and the generic information scheduled to coincide with the first phase of the development of the transportation system (see Table 1). Program-specific information will follow further technical developments, site selection, and the definition of specific transportation routes. 
OCRWM will develop Information resources in several broad categories. These categories include:

- Written material such as pamphlets, brochures, fact sheets, program reports, and press releases. To ensure the appropriate level and focus of content, these materials will be developed with particular audiences in mind (Congressional staffs, State leglslatures, Tribal councils, business concerns, etc.).

- Visual-alds including films, slide shows, exhibits, and demonstrations.

- Transportation experts who possess a thorough awareness of transportation policies and programs and competence in group dynamics. While OCRWM management will constitute the primary component of this resource category, speakers external to the DOE who possess a particular expertise and interest to audiences will also be asked to speak on transportation subjects. As the requirements for this category expand, the establishment of a mechanism for sharing responsibility--such as a "transportation speaker's bureau"--can be considered.

- Technical reports. The OCRWM w1ll make these reports available in preparation for workshop participation and public hearings.

- Operational planning documents. These documents w111 also be made available to States, Tribes, localities, and utilities as an aid to their planning.

Schedules for developing these resources will reflect the various phases of the transportation program. For example, in the early stages of the program, the emphasis will be on production of generic transportation materials to relnforce public knowledge of transportation requirements and procedures. Following development of casks and announcement of cask fleet procurement awards, material will be generated to acquaint the public with the features of selected casks designs. As the OCRWM program progresses toward site selection, public information forums in the local areas will use many of the resources described above.

\subsubsection{Information Dissemination}

The resources developed w11 be used in a variety of complementary ways to inform the public and to provide for a fuller participation by the communication network. In some cases, the information resources provided will be the first step in establishing dialogue between the OCRWM and public interest groups, the media, and the interested public. For this reason, timeliness and provision of appropriate information are critical to the success of the network operations.

Speakers on transportation issues will provide information to the public through conferences and meetings, seminars, workshops, press briefings, and Congressional or public hearings. 
The OCRWM plans particular emphasis on routinely providing media contacts, with background information and announcements of upcoming events and decisions. Another potential area of communication will be to provide educational resources to schools and universities.

The OCRWM is also generating information for specialized groups within the communications network. Material will be produced and disseminated to the transportation business community regarding such areas of business interests as requirements for cask and equipment development and transportation services. Details of this business-related information activity are provided in the Transportation Business Plan. Information is also being developed on specific transportation issues. For a description of this latter effort, which affects many of the groups within the communication network, see Chapter 4.

\subsubsection{Coordination of Activities}

To ensure consistency and to avoid duplication of effort, the OCRWM w111 coordinate public information policies and implementation plans with other OCRWM program elements, the regulatory agencies, and other elements of the communication network external to the OCRWM. All resource development activities will be conducted within guidelines and procedures established by the Office of Policy and Outreach.

Identification of available capabilities most appropriate to develop and disseminate information to the public is an early and integral task of program implementation. For example, the regional expertise of a project office may qualify it as the most likely producer of a pamphlet on facility/transportation interfaces. The coordination activities of the OCRWM and its contractors will ensure that the most appropriate and efficient means are chosen. Network participation during these planning stages will further define the resources that will be useful and desirable to the network.

\subsection{Support for Network Participation}

The OCRWM will facilitate participation in implementing the objectives of this Plan through a system of arrangements* with governmental bodies, and professional and technical organizations. Assistance is already provided by the NWPA for participation by potential host States and affected Tribes in site-selection program activities, including those related to transportation. In addition, contracts will be inftiated and administered through a DOE Operations office, for the purpose of studying reglonal or specific transportation issues. Such contracts may be established with national laboratories (laboratories that are owned by the DOE and operated by contractors); with organizations of States, Tribes, or local government; and with technical or professional organizations having a particular interest or expertise in the issues being studied.

* Grants, cooperative agreements, or contracts, as appropriate. 
These contracts will provide the resources to support consultation and ' interaction with interested groups and Individuals. Findings and recommendations will be assimilated and evaluated, and a resulting report will be submitted to the OCRWM. This report will assist the OCRWM in considering and evaluating various policy options to resolve identified issues or to otherwise enhance the development and implementation of the NWPA transportation program. Selection of participating organizations will reflect the need to ensure broad-based representation in OCRWM transportation activities.

\subsection{Mitigation of Transportation Impacts}

As directed by the NWPA, following the selection of facility sites, the OCRWM will provide financial and other assistance to host States and affected Tribes, and local governments to mitigate identified impacts associated with the construction and operation of a repository and MRS facility (if authorized by Congress). In consultation with such host States, affected Tribes, and local governments, the OCRWM will determine if assistance is needed and if provision from the Waste Fund is statutorily allowable.

In addition to providing assistance to the governmental bodies listed above, the OCRWM will evaluate the potential need for, and appropriate guidelines for, assistance to non-host States and other governmental bodies that may be impacted by NWPA transportation. 
Consistent with the planning principles discussed in Chapter 1 , the OCRWM (in cooperation with interested parties) will address and work to resolve transportation issues in a manner which balances responsiveness to State, Tribal, and local interests with responsible management of the transportation program and Nuclear Waste Fund expenditures. Such a process requires the judicious welghing of interests in order to achieve satisfactory issue resolution.

In an effort to foster a climate conducive to the identification and resolution of transportation issues, the OCRWM has initiated a dialogue with a wide range of parties having an interest in waste transportation. These interactions have led to the identification of numerous transportation issues related to the procedural, operational, and financial implications of nuclear waste transportation. To promote public participation in the review and evaluation of various transportation options and to assist in information dissemination, the OCRWM initiated the development of a series of transportation discussion papers.

The development of those papers, and their release for public comment, represented preliminary efforts of the OCRWM to Identify and discuss transportation institutional issues. Formal mechanisms for continued issue identification, and a process for addressing and resolving such issues, are described in this chapter.

\subsection{Issue Identification}

Issues related to the transportation of spent fuel and high-level waste will be 1dentified by the OCRWM through:

- Participation in meetings, briefings, and workshops.

- OCRWM review of current transportation developments.

- Submission of written comments from interested parties to the OCRWM.

Detalls of the processes used for issue identification are provided below.

\subsubsection{Transportation Meetings, Briefings, and Workshops}

Transportation issues related to the waste-management program may be raised at numerous briefings and meetings involving the OCRWM and interested parties. Such meetings or briefings include general OCRWM meetings or briefings with potential host states for repositories and an MRS facility; Congressional briefings; meetings with national and regional State government organizations and individual State and local governments; meetings with the governments and organizations of Indian Tribes; meetings with industry and nuclear power utilities and their representative organizations; meetings with the general public and interest organizations; and meetings with other Federal agencles having regulatory authority or other transportation authority 
associated with the waste-management program. These meetings may be initiated by the OCRWM or others.

In order to formally identify issues raised at such meetings and advise or notify all interested parties of those issues, the OCRWM will review transportation developments and issues in the OCRWM Bulletin. The OCRWM Bulletin is published by the Office of Policy, Integration and Outreach approximately every six weeks.

In addition to the meetings or briefings described above, the OCRWM will hold transportation workshops. The workshops will be designed to facilitate on-going two-way communication between the OCRWM and all interested parties and will be conducted specifically for the purpose of identifying and defining transportation issues, clarifying OCRWM policy options, setting a time frame for OCRWM policy decisions, and resolving issues where possible. The workshops will be held approximately once every year. Additional workshops will be held as needed to focus on a given transportation issue or group of 1ssues. In preparing for such workshops, the OCRWM will consult with other DOE program offices to ensure adequate coordination on transportation issues of common interest.

Notice of a workshop's date, location, and transportation issues of primary focus will be provided through letters of invitation, and publication in the OCRWM Bulletin. Where broad interest and participation in a workshop are expected, notice of the workshop will be published in the Federal Register. In order to ensure that all interested parties are kept advised of the transportation issues discussed at such workshops, brief workshop summaries will also be published in the OCRWM Bulletin.

\subsubsection{OCRWM Review of Current Transportation Developments}

The OCRWM will monitor current developments having an impact on waste transportation and will include a brief review of transportation-related activities in the OCRWM Bulletin. Such developments may include:

- Regulatory changes or actions at the Federal level.

- Court and Federal agency decisions, rulings, and orders.

- Proposed Federal legislation and Congressional activities.

- Utility and industry activities that may affect waste transportation.

- Developments at the State or Tribal level that may.affect waste transportation.

- Results of research and development and other studies that may affect transportation.

Through such transportation monitoring activity, the OCRWM will increase its ability to anticipate, Identify, and discuss transportation issues. 


\subsubsection{Review of Written Comments Submitted to OCRWM}

The OCRWM encourages an on-going identification process for transportation issues through written comments by interested parties. Comments may be addressed to:

The Office of Storage and Transportation Systems Office of Civilian Radioactive Waste Management U.S. Department of Energy 1000 Independence Avenue, S.W. Washington, D.C. 20585

Issues so identified will be incorporated into a list maintained by the OCRWM and w11l be addressed in the same manner as issues identified by any other means.

\subsection{Process for Addressing Transportation Is sues}

Transportation issues will be evaluated and addressed by the OCRWM through a flexible process that will include one or more of the following strategies: development of transportation discussion papers; workshops; contracts with representative organizations; and cooperative agreements and/or interactions with Federal agencies and State, Tribal, and local governments. Policy positions related to transportation issues will be developed through consultation among the OCRWM's Office of Storage and Transportation Systems; Office of Policy and Outreach; Office of Geologic Repositories; the DOE's Office of General Counse1; and other DOE offices and Federal agencies as required.

\subsubsection{Transportation Issues Discussion Document}

As transportation issues are identifled, policy options for issue resolution will be addressed through the annual release of a Transportation Issues Discussion Document. The document will present a formal mechanism by which the OCRWM can detail policy options and transportation planning strategies and note progress toward issue resolution. If an issue has been resolved, or if the OCRWM policy on an issue has been decided, the document will so note. The first such document will be issued in the spring of 1986, to coincide with the publication of the final Transportation Institutional Plan. Thereafter the Transportation Issues Discussion Document will be revised annually to reflect newly acquired information, program events and decisions, and public comment.

The document will address specific transportation issues through Individual discussion papers. Discussion papers will be prepared in a standard format having the following elements:

- The background or an overview of the issue.

- A 1ist of associated issue elements.

- A discussion of each issue element including, where appropriate (and as planning continues), the following: 
- OCRWM policy options, constraints to policy decisions (such as the need for related information, or legal limits), elements of an Issue that remain unresolved, and the predicted time frame for reaching an OCRWM policy decision.

- A description of the OCRWM's intended or anticipated role in the event that the DOE lacks authority to take a primary role in resolving an issue (e.g., the DOE may assume a reinforcing role by cooperating with other Federal, State, Tribal, or local agencies that are responsible for making a final decision on the issue, or take no action).

- Opportunities for public involvement in the evaluation of OCRWM policy options.

Discussion papers that have been issued to date by the OCRWM will be revised for inclusion in the Transportation Issues Discussion Document. Such papers will reflect public comment and conform to the standard format detailed above.

\subsubsection{Transportation Workshops}

As discussed above, transportation workshops will be sponsored by the OCRWM approximately once a year in an effort to identify and discuss issues. In addition, the workshops are expected to assist the OCRWM in the development of transportation institutional policies. Updated versions of the Transportation Issues Discussion Document will be reviewed by the OCRWM and the workshop participants, and timing assumptions and policy options will be discussed.

\subsubsection{Analysis by Representative Organizations}

As noted in Section 3.4, the OCRWM will initlate through a DOE Operations office a series of contracts for the purpose of studying reglonal or specific transportation issues. These contracts may be with the national laboratories; with organizations of State, Tribal, or local governments, or their representatives; or with private-sector organizations of a transportationrelated character.

Such contracts would require the contractor to consult and interact with parties having a particular expertise or interest in the issues being studied and to assimflate and evaluate the findings and recommendations. The intent is to permit an exchange of views and experience in order to gain maximum objectivity in issue analysis. A resulting report would be provided to the OCRWM for consideration and evaluation of various policy options.

The work product of all such contracts should provide the OCRWM with a sound perspective on representative interests concerning the various transportation issues. The views and recommendations expressed will provide further input and balance to OCRWM decisionmaking for a safe, efficient, cost-effective, and publicly acceptable transportation system. 
The OCRWM will strengthen its coordination with other Federal agencies (e.g., the DOT, the NRC, and the FEMA) having regulatory authority or responsibilities that will affect the transportation of radioactive waste. Initial steps in this area have already been taken (and are discussed in Chapter 2). A procedural agreement between the DOE and the NRC on packaging certification was reached in 1983 (48 Fed. Reg. 51875). A memorandum of understanding is now being developed by the OCRWM and the Research and Special Programs Administration of the DOT to delineate the respective departmental responsibilities and to establish common planning assumptions for the implementation of transportation requirements under the NWPA. In addition, the DOT and the DOE are cosponsoring a joint study of prenotification of hazardous materials shipments. The DOE is also a participant in the emergency-preparedness activities of the FEMA. Continued coordination should allow the OCRWM to avoid the duplication of planning efforts and to identify and resolve, as early as possible, any regulatory issues or deficiencles that may impede waste transportation.

\subsection{Procedures for Resolving Issues}

Following consultation with representatives of States, Indian Tribes, local governments, industry and utilities, and all other interested parties, and careful evaluation of alternatives for resolving specific transportation issues, the OCRWM will announce a policy decision. Notice of the policy decision will be published in the OCRWM Bulletin, and will include specific actions that the OCRWM will take to Implement the decision. Such activities may include:

- OCRWM action, where the OCRWM has appropriate authority.

- Cooperation with other agencies, where such agencies have ultimate responsibility for activities or decisions.

\subsubsection{OCRWM Action}

After the evaluation of specific transportation issues, the OCRWM may determine that direct action on the part of the DOE (consistent with the DOE's legal authority) is necessary to promote the timely development and implementation of a safe, publicly-acceptable, efficient, and cost-effective NWPA transportation system. Such actions may include:

- The development of new operating procedures, with the issuance of related orders.

- Formal rulemaking, consistent with the provisions of the Department of Energy Organization Act (42 U.S.C \$7191) and the Administrative Procedures Act (5 U.S.C \$553).

- Recommendations to Congress for new legislation.

- Provision of technical and/or financial assistance. 
i 4.3.2 Cooperation with Other Agencies

Where the OCRWM determines that an authority (whether Federal, State, or Tribal) other than the DOE has ultimate responsibility for certain activities or dectsions, the OCRWM's policy decision will indicate such a finding and describe the process by which the OCRWM will cooperate with such an authority to resolve transportation issues. Such cooperation may include developing procedural agreements and providing technical and/or financial assistance.

The integrated process for identifying transportation issues and working toward final issue resolution is detailed in Figure 4. 
- MEETINGS/BRIEFINGS/WORKSHOPS

- ONGOING OCRWM REVIEW OF

TRANSPORTATION DEVELOPMENTS

- PUBLIC COMMENT/RECOMMENDATIONS

- TRANSPORTATION ISSUES

- DISCUSSION DOCUMENT/DISCUSSION PAPERS

- WORKSHOPS /CONSULTATION WITH INTERESTED PARTIES

- CONTRACTS WITH REPRESENTATIVE ORGANIZATIONS

- INTERACTION/COOPERATION WITH OTHER FEDERAL AGENCIES, DOE PROGRAM OFFICES
ISSUE IDENTIFICATION

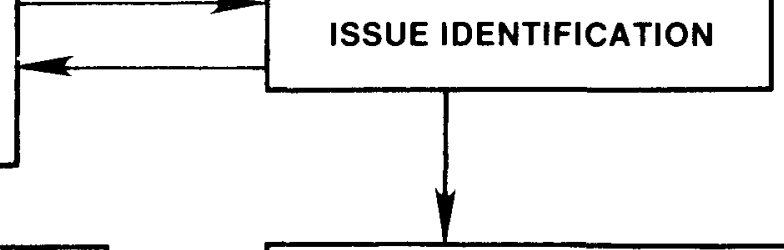

REVIEW OF TRANSPORTATION ISSUESI EVALUATION OF OCRWM POLICY OPTIONS
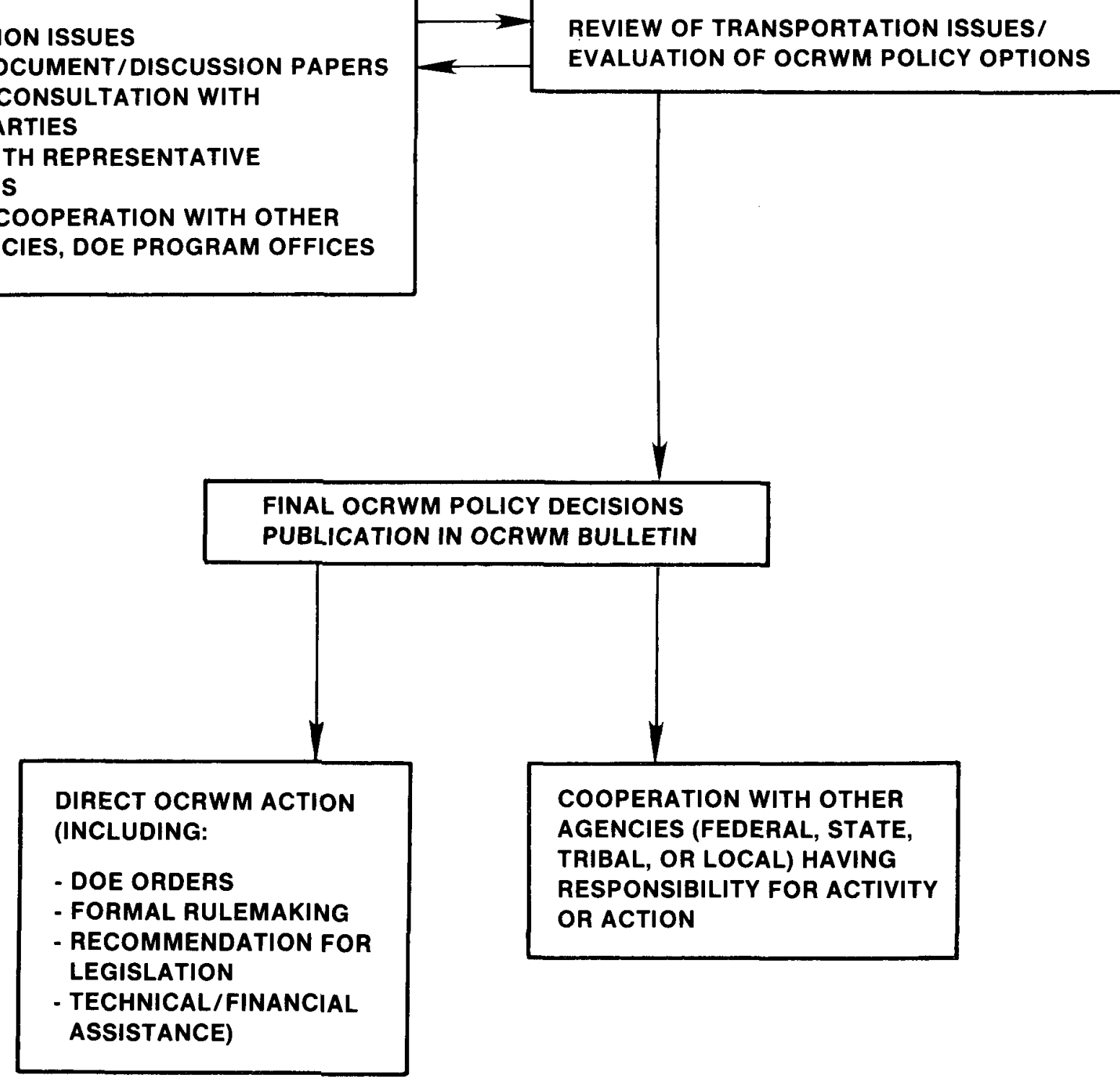

Figure 4. Management of transportation issues. 


\section{LIST OF ACRONYMS}

C \& C - Consultation and cooperation

CFR - Code of Federal Regulations

DOE - United States Department of Energy

DOT - United States Department of Transportation

EPA - Environmental Protection Agency

FEMA - Federa1 Emergency Management Agency

ICC - United States Interstate Commerce Commission

MOU - Memorandum of understanding

MRS - Monitored retrievable storage

MTU - Metric tons of uranfum

NRC - United States Nuclear Regulatory Commission

NWPA - Nuclear Waste Policy Act of 1982

OCRWM - Office of Civilian Radioactive Waste Management (within the DOE)

OPIO - Office of Policy and Outreach (within OCRWM)

OSTS - Office of Storage and Transportation Systems (within OCRWM)

QA/QC - Quality Assurance/Quality Contro1

RFP - Request for Proposals

SARP - Safety analysis report for packaging 
Act - the Nuclear Waste Policy Act of 1982 (Pub11c Law 97-425).

affected Indian Tribe - any Indian Tribe (1) within whose reservation boundarles a monltored retrlevable storage facility, a test and evaluation facility, or a repository for high-level radioactive waste or spent fuel is proposed to be located or (2) whose federally defined possessory or usage rights to other lands outside the reservation's boundaries arising out of Congressionally ratifled treaties may be substantially and adversely affected by the locating of such a facility, provided that the Secretary of the Interior finds, upon the petition of the appropriate governmental officials of the Tribe, that such effects are both substantial and adverse to the Tribe.

authorized system - the waste-management system authorized by the Act and consisting of a geologic repository, the necessary transportation system for moving the wastes to the repository, the provision for Federal interim storage, and cooperation with the private sector in demonstrating the dry storage of spent fuel at reactor sites.

biosphere - the part of the Earth in which life can exist, Including the lithosphere, the hydrosphere, and the atmosphere.

carriage equipment - any vehicle and associated equipment used to transport waste to NWPA facilities.

carrier - for NWPA transportation, a person (including companies) engaged in transporting waste by land or water to NWPA facilities.

cask - a container for shipping spent nuclear fuel or high-level waste that meets all applicable regulatory requirements.

commercial high-level radioactive waste - the high-level radioactive waste resulting from the reprocessing of spent fuel from commercial nuclear reactors.

commerclal nuclear reactor - a civilian nuclear power plant operated to produce heat for generating electricity.

communication network - see "network".

consolidation - an operation during which the upper and lower tie plates of spent-fuel assemblies are removed, the spacer grids and any other structural members of the assembly are removed, and the fuel tubes are collected and formed into a closely packed bundle for insertion into a canister.

* For definttions of acronyms, see the preceding list of acronyms. 
consultation-and-cooperation $(C \& C)$ agreement - the agreement required by the Nuclear Waste Policy Act. The Secretary of Energy is required to attempt to enter into a C\&C agreement with a State that hosts a site approved for characterization or with an affected Indian Tribe.

defense waste - waste derived from atomic-energy defense activities.

dual-purpose cask - a cask that could serve as a storage module as well as a transport cask.

emergency response - the proceedings and activities carried out by Federal, State, and local officials in response to a transportation accident involving radioactive waste.

Federal interim storage - see "interim storage facility."

full-service contract - a contract under which a single contractor will provide all transportation services required to ship and dispose of clvilian radioactive waste.

geologic repository - a system, to be licensed by the NRC, that is intended to be used for the disposal of radioactive waste in geologic formations.

high-level radioactive waste (HLW) - (1) the highly radioactive material resulting from the reprocessing of spent nuclear fuel, including 1iquid waste produced directly in reprocessing and any solid material derived from such liquid waste that contains fission products in sufficient concentrations; and (2) other highly radioactive materlal that the Nuclear Regulatory Commission determines by rule, or the DOE determines by order, consistent with existing law, to require permanent isolation.

improved-performance system - a waste-management system that includes an MRS facility as an integral part.

integrated waste-management system - a waste-management system in which all components and elements are optimized to work with the other components and elements. This system is usually meant to include an integral MRS facility.

interested Indian Tribes - Indian Tribes who, because of their proximity to nuclear waste shipping routes have an interest in the waste-management program.

Interim storage facility - a Federally owned and operated system that would provide storage for no more than 1,900 metric tons of spent fuel from commercial reactors whose owners cannot reasonably provide adequate storage capacity at the reactor site.

Mission Plan - full title: Mission Plan for the Clvilian Radioactive Waste Management Program. Document required by the Act to discuss objectives, strategy, status, and management of the Civilian Radioactive Waste Management Program. The Mission Plan was released in July 1985. 
monitored retrievable storage - a concept for temporarily storing waste or spent fuel. The waste and spent fuel would be continuously monitored and would be stored in such a way that it could be retrieved for shipment to a repository. In the improved-performance system, the principal functions of a MRS facility would be spent-fuel consolidation and other waste-handling activities.

network - an interrelated group whose interests and interactions focus on waste transportation.

Nuclear Waste Fund (NWF) - the fund established by the Act to ensure that the costs of waste management are borne by the owners and generators of the waste.

OCRWM Bulletin - publication of program activity issued on a regular basis by the OCRWM's Office of Policy, Integration and Outreach.

package - pertaining to transportation, the packaging and its radioactive contents.

packaging - pertaining to transportation, the assembly of components necessary to ensure compliance with DOT regulations. It may consist of one or more receptacles, absorbent materials, spacing structures, thermal insulation, radiation shielding, and devices for cooling or absorbing mechanical shocks.

packaging certification - the certification by NRC or DOE that packaging used for the transport of spent fuel and high-level radioactive waste is sufficient to prevent the loss or dispersion of its radioactive contents, provides adequate radiation shielding and heat dissipation, and prevents the occurrence of spontaneous nuclear reactions under normal (incident-free) and accident conditions of transportation.

quality assurance - all the planned and systematic actions necessary to provide adequate confidence that a structure, system, or component is constructed according to plans and specifications and will perform satisfactorily.

radioactive waste - high-level waste (HLW), spent fuel, and other radioactive materials that are received for emplacement in a geologic repository.

repository - see "geologic repository."

reprocessing - the mechanical and chemical process by which irradiated nuclear fuel is separated into waste material to be disposed of, and useful materials, such as thorium, uranium, and plutonfum, to be reused as nuclear fuel.

request for proposals - a formal announcement in the Commerce Business Dally of the Federal Government's intent to purchase certain goods or services and an invitation for vendors to submit a bid to supply these goods or services. The announcement coincides with the issuance of a comprehensive document entitled "Request for Proposal" with all details of the requirements and all relevant Federal regulations. 
shipper - party responsible for the movement of waste even though the material may be physically transported by someone else; under the NWPA, DOE w111 be the shipper for waste shipments to NWPA facilities.

solidification - the conversion of liquid high-level waste to a solid form, such as glass.

spent-fuel rods - the metal tubes that contain uranium-bearing fuel pellets and are removed from a reactor after irradiation. Part of the spent-fuel assemb1y.

spent fuel - fuel that has been withdrawn from a nuclear reactor after irradiation.

storage - retention of high-level radloactive waste, spent fuel, or transuranic waste with the intent to recover such waste or fuel for subsequent use, processing, or disposal.

storage pool - a concrete chamber that is filled with water and is used for the temporary storage of spent fuel at a reactor site.

transportation business plan - the program document that will provide information on contracting procedures, equipment requirements, funding availability, and other areas of interest related to conducting the business of developing the transportation capability.

transportation service contractor - private company under contract and responsible for: assembling a transport fleet; making carriage arrangements; providing inspection, maintenance, and repair services; the training of security and operations personnel; and managing transportation operations.

waste management - the planning, execution, and survelllance of essential functions related to the control of radioactive waste, including treatment, solidification, temporary storage, and isolation.

waste-management system - the collection of facilities, equipment, personnel, and sites to be developed by the U.S. Department of Energy for the permanent disposal of spent fuel and high-level waste. 
$$
\text { . }
$$ 


\section{LIST OF FIGURES}

$i^{\prime}$

Figure

Title

Page

1

Evolution of the transportation plan . . . . . . . 6

2

OCRWM organization chart . . . . . . . . . . . 9

3

Transportation program schedule... . . . . . . 18

4

Management of transportation issues. . . . . . . 32

\section{LIST OF TABLES}

Table

1
Title

Page

Relationship between technical development and institutional planning . 
$$
\text { . }
$$ 
FEDERAL AGENCY TRANSPORTATION RESPONSIBILITIES AND APPLICABLE REGULATIONS AND ORDERS

\section{Department of Transportation}

The Department of Transportation Act of 1966 recognized the need to organize transportation policies to assure national economic growth, security, and stability, and therefore, established the Department of Transportation (DOT). The DOT is thus empowered to be the lead agency with jurisdiction over the regulation of commercial nuclear materials transportation. It carries out its responsibilities through four administrations (Federal Highway Administration, Federal Railroad Administration, Federal Aviation Administration, and U.S. Coast Guard) and its various offices.

The Federal Raflroad Safety Act of 1970 was enacted to promote safety in railroad operations and to reduce railroad-related accidents, deaths, injuries, and damage involving any carrier of hazardous materials, including nuclear materials. The Secretary of Transportation, through the Federa1 Railroad Administration, has the responsibility for prescribing appropriate rules, regulations, orders, and standards for all areas of railroad safety, including nuclear materials transportation.

Because of increasing public concern, the Hazardous Materlals Transportation Act of 1974 (HMTA) was passed to minimize risks to 1ife and property (that are inherent in commercial transportation of hazardous materia1s) by increasing the regulatory and enforcement authority of the Secretary of Transportation. The HMTA is the princtpal Federal statute that governs the regulation of hazardous materials transportation and the relationship between Federal, State, and local regulation in this fleld. The Act outlines the areas over which DOT has authority (e.g., packaging, labeling, routing, and container fabrication). It also prohibits transportation of nuclear materials on passenger alrcraft unless the materials are to be used for research or medical diagnosis/treatment.

The Code of Federal Regulations describes the detalls and procedures for nuclear materials transportation accorded to the DOT.

\section{CFR Part 172}

Subpart B of Part 172 lists the materials designated by the Department of Transportation as hazardous for commercial transportation. A table includes a description of nuclear materials, and requirements for the shipping name, class, labeling, and packaging.

Subpart $C$ gives the requirements for the shipping papers for all hazardous materials, including nuclear materlals, with a description of the materials and the shippers' certifications.

Subpart D discusses marking requirements (e.g., proper shipping name) according to type of package and mode of transport. Subpart $E$ focuses on the required labels, based on the properties and amounts of all hazardous materials including radioactive materials being carried. 
Part 172 defines nuclear materials as hazardous, and states ways in which., the hazardous properties of each shipment are to be made known to the proper authorities and the public through use of shipping papers, marking requirements, placarding and labeling.

49 CFR Part 173

Subpart I defines the types, classes, and quantities of materials including fissile materials. This subpart also outlines general packaging and shipment requirements for approved packages, and for international shipments and forelgn-made packages. The latter must meet IAEA requirements. The discussion of packaging requirements is based on the individual radioactive properties of the individual nuclear materials. The packaging properties considered include leak resistance, corrosion resistance, absorption rate, cushioning, and resistance to explosive materials.

\section{CFR Part 174}

Subpart $\mathrm{K}$ states the special requirements for radioactive materials carried by rail. This includes lading techniques, number of packages to be placed per car, labeling, decontamination and cleaning of cars after use, and actions to take following incldents involving leakage. Subpart $\mathrm{K}$ focuses on the general shipping regulations for nuclear materials for carrlage by rafl.

\section{CFR Part 176}

Subpart $M$ gives the requirements for nuclear materials transportation by vesse1. Three major issues of interest are the location (placement) of each package on the vesse1; the actions to be taken following leakage or shifting of radioactive materials; and contamination control for the compartments used for the nuclear materials transportation.

\section{CFR Part 177}

Part 177 presents the regulations generally required for hazardous materials to be transported by public highway; $1 . e .$, accident and missing shipments reporting procedures; tunne1s, rules for the use of labels, and shipping papers; retesting cargo tanks, etc. of special note is Section 177.825, which provides routing and training requirements for highway shipments of radioactive materials. Appendix A of Part 177 provides a DOT policy statement of the relationships between Federal, State, and local routing requirements.

\section{CFR Chapter 1}

Chapter 1 describes Coast Guard regulations that affect shippers and carriers of nuclear materials in a general fashion, such as aids to navigation, navigation requirements for inland waters, anchorages, security of vessels, bridges, marine oil pollution liability and compensation, boating safety, etc. 
Chapter 1 of Title 23 provides background information about the general management and administration of the Federal Highway Administration (FHWA), and its functional responsibilities; for example, research and development, engineering and traffic operations, right-of-way, environmental impact of highways, and public transportation.

46 CFR

The entire title pertains to barge transport.

\section{CFR Chapter 2}

Chapter 2 of 49 CFR is a discussion of the operating structure for the Federal Railroad Administration and of the numerous regulatory areas under DOT jurisdiction, for example, safety enforcement procedures, noise emission compliance regulations, track safety standards, freight car standards, power brakes, signal systems, etc.

\section{CFR Chapter 3}

Chapter 3 is divided into two parts that, together, outline the general and safety regulations for motor carrier transportation. Subchapter A, "General Regulations", touches lightly upon the organization and delegation of powers and duties within the FHWA, and explains bridge and tolls rules and noise emissions standards. The bulk of the Chapter, Subchapter B on motor carrier safety regulations, deals with a number of issues that affect general motor carrier arrangements with States, qualifications of drivers, and reporting of accidents.

\section{CFR Chapter 5}

Chapter 5 details the institutional structure and responsibilities of the National Highway Traffic Safety Administration (NHTSA), and presents guidelines for highway safety. The former focuses on the bureaucratic structure of the NHTSA, delegation of powers and tasks, information-gathering powers, and adjudicative procedures.

This chapter does not deal with nuclear materials transportation per se, but does affect such commerce by outlining safety procedures that concern all shippers and carriers that utilize national highways.

\section{Nuclear Regulatory Commission}

The Energy Reorganization Act of 1974 abolished the Atomic Energy Commission and divided its roles and tasks between two agenctes. The Energy Research and Development Administration (now DOE) was given responsibility for commercial nuclear energy research, development, and demonstration activities, and also for military applications and naval reactor programs. The Nuclear Regulatory Commission (NRC) was given the responsibility for licensing and regulating commercial activities. 
The NRC has three offices that review the transportation of nuclear materials: the Office of Nuclear Material Safety and Safeguards, the office of Inspection and Enforcement, and the Office of Nuclear Regulatory Research.

The Transportation Certification Branch of the Office of Nuclear Materials Safety and Safeguards, evaluates the design of packages used for high-level radioactive waste and spent-fuel transportation, according to standards developed and implemented by the NRC.

The Office of Inspection and Enforcement has responsibility for inspecting the fabrication of transportation packages, and inspecting the licenses for high-level radloactive waste and spent-fuel transport, according to both NRC and DOT standards and regulations. In addition to the main office in Washington, inspection and enforcement activities are carried out through five field offices.

Through the Transportation Research Branch of the Office of Nuclear Regulatory Research the Commission contracts for research deemed necessary for performing licensing and regulatory functions related to high-level nuclear materials transportation. The Office of Nuclear Regulatory Research is responsible for writing regulations, including those that affect transportation of high-level radioactive waste and spent nuclear fuel.

The Code of Federal Regulations describes the details and procedures for nuclear materials transportation accorded to NRC.

10 CFR Part 9

The regulations in Part 9 implement: 1) the provisions of the Freedom of Information Act, 5 U.S.C. 552, with respect to avallability of NRC records to the public for inspection and copying; 2) the provisions of the Privacy Act, with respect to disclosure and availability of certain NRC records maintained on individuals; and 3 ) the provisions of the U.S. Government in the Sunshine Act, 5 U.S.C., 552b, with respect of opening NRC meetings to public observation.

Part 9 influences nuclear materials transportation by contributing to the public information process. The regulations provide the public with opportunities to be knowledgeable about NRC decisions and policies on transportation as well as other related issues.

10 CFR Part 19

The regulations in Part 19 formulate requirements for notices and Instructions for, and reports by, licensees to individuals responsible for ascertaining licensee compliance with the provisions of the Atomic Energy Act (as amended), 42 U.S.C. 2021; Title II of the Energy Reorganization Act, 42 U.S.C. 5801; and regulations, orders, and 1icenses regarding radiological working conditions. The regulations apply to all persons who recelve, possess, use, or transfer nuclear materials that are licensed by the NRC. 
Part 19 affects nuclear materials transportation by assuring that all individuals working in any type of restricted area shall be kept informed of storage, use, or transfer of nuclear materlals, and of related radiation levels. Workers will be advised of health precautions and procedures to minimize radiation exposure during transport. The regulations provide for NRC inspector consultation with workers concerning matters of occupational radiation protection and other related concerns. Moreover, Part 19 establishes procedures for addressing violations of these regulations.

10 CFR Part 20

Part 20 sets out the standards for personnel protection against radiation. It establishes a foundation by defining units in a radiation dose and units of radioactivity in general. Several additional topics are covered in this part. First, standards on permissible doses, levels, and concentrations include such issues as dose standards for people in restricted areas, in unrestricted areas, exposure of children, medical diagnosis and therapy, etc. Second, standards on precautionary procedures include worker and personnel monitoring for radiation doses; caution signs, labels, signals and controls; procedures for handling and storing packages; etc. Third, standards on waste disposal address procedures for obtaining approval of proposed disposal procedures; and different methods of disposal, such as in soil and by incineration. Finally, standards are set out to clarify the requirements for records, reports, and notification of incidents.

\section{CFR Part 21}

The regulations in Part 21 establish procedures and requirements for reporting defects in nuclear components and materials and for noncompliance with components and materials manufacturing standards. The regulations apply to any individual director or responsible officer of a firm constructing, owning, operating, or supplying the components or materials of an NRC licensed or regulated facility. If the responsible person has information reasonably indicating: 1) that the component or material fails to meet the standards; or 2) that serious defects may exist and create a safety hazard, they must immediately notify the NRC of such failure to comply or such defect. Part 21 affects nuclear materials transportation by requiring manufacturers and suppliers of components and materials to identify faulty products, preferably before shipments occur.

\section{CFR Part 51}

Part 51 establishes standards for protecting the environment against the potential hazards presented by the nuclear industry. Specifically, it establishes requirements for environmental impact statements; environmental reports of all nuclear facilities at the construction permit and operating license stages; environmental reports and administrative procedures for materials licensing; and, finally, for administrative procedures on communicating with the public, for example, through public hearing and notices in the Federal Register. 
Part 51 establishes radiation standards to protect the environment against exposure to radiation during transport, delivery, and disposal activities; and outlines public hearing procedures on transportation and disposal methods, and requirements for notices to the public.

\section{CFR Part 71}

Part 71 establishes criterla for shipping licensed nuclear materials in various types of packages. The discussion focuses on several areas. First, general licensing procedures for shipment are set out. Second, the requirements for the actual license application (e.g., package description, package evaluation, quality assurance) are explained. Third, NRC standards for all packaging are laid out according to type of material to be contained. Finally, Part 71 describes operating procedures, quality assurance instructions, and inspection and testing requirements.

\section{CFR Part 73}

Part 73 prescribes requirements for the establishment and maintenance of physical protection systems. Sections 73.25 through 73.37 focus on special nuclear material and spent fuel in transit, and deal with requirements for physical communications requirements.

Part 73 outlines shipper and carrler requirements for planning and scheduling, such as obtaining advance approval of routes prior to shipment, and making arrangements to be made with law enforcement agencies along the route in the event of an emergency.

National Transportation Safety Board

The mission of the National Transportation Safety Board, created in 1971, is to promote transportation safety by conducting independent investigations of accidents and other safety problems and by formulating safety improvement recommendations.

The Board is responsible for investigating accidents and determining their cause, making safety recommendations, and reporting the facts and circumstances of all transportation accidents that are catastrophic, involve problems of recurring character, or should otherwise be investigated in the judgment of the Board. In addition, the Board makes recommendations on matters pertaining to transportation safety and is a catalyst for transportation accident prevention.

The Board previously reported to the DOT, but the Independent Safety Board Act of 1974 declared the National Transportation Safety Board an independent body and strengthened its power to Investigate transportation accidents and make recommendations on regulations.

The section of the Code of Federal Regulations that describes the details and procedures for nuclear materlals transportation according to the National Transportation Safety Board is Title 49, Chapter VIII. The regulations make provisions for independent inquiries and determinations about causes of transportation accidents, and make recommendations on safe highway carriage of nuclear materials. 
The Interstate Commerce Commission (ICC) regulates certain economic aspects of interstate surface transportation, including trains, trucks, buses, inland waterway and coastal shipping, freight forwarders, and express companies. The regulations vary with the type of transportation; however, they generally involve certification of carriers seeking to provide transportation for the public, rates, adequacy of service, purchases, and mergers. The ICC's mission is to ensure that regulated carriers will provide the public with rates and services that are falr and reasonable.

On matters within its jurisdiction in the transportation economics area, the ICC acts to prevent unlawful discrimination, destructive competition, and rebating. It also has jurisdiction over the use, control, supply, movement, distribution, exchange, interchange, and return of railroad equipment. Under certain conditions, it is authorized to direct the handling and movement of traffic over a rallroad and distribution over other lines of railroads.

In the transportation service area, the ICC grants operating authority to trucking companies, bus 1ines, freight forwarders, water carriers, and transportation brokers.

Nuclear materlals transportation is impacted through the authority entrusted to the ICC to establish rules and tariffs for carrier traffic, to certify and license carriers, and to establish the value of property owned and used by each carrier.

The section in the Code of Federal Regulations that describes the details and procedures for nuclear materials transportation according to the ICC is Title 49, Chapter X, Subchapter D. Under the guldelines discussed in Subchapter $D$ on tariffs and schedules, ICC regulates economic aspects of surface nuclear materials shipments including rate setting for all modes of transport except aircraft.

Federal Emergency Management Agency

Under the provisions of Executive Order 12148 (July 20, 1979), the Federal Emergency Management Agency (FEMA) is responsible for establishing Federal policies for, and coordinating, all civil emergency planning, management, mitigation and assistance functions of Federal executive agencies. In addition, the FEMA is responsible for coordinating Federal and state participation in developing emergency response plans.

Under this mandate, the FEMA has assumed the responsibllity for coordinating the development of the interim Federal Radiological Emergency Response Plan (49 Fed. Reg. 35896). The interim plan has application in the event of an accident involving the transportation of spent fuel and radioactive waste, and is designed to provide coordinated Federal response in support of state and local governments. It is important to note that under the FEMA's coordinated response plan, State and local governments have primar:y emergency responsibilities, and Federal assistance is to be made available only if requested. 
In order to assist state and local agencles in developing and testing radiological emergency response plans, the FEMA established the Federal

Radiological Preparedness Coordinating Committee (FRPCC). In December 1982, the FRPCC's Subcommittee on Transportation Accidents (composed of

representatives from the U.S. Department of Energy, Nuclear Regulatory Commission, FEMA, and other Federal and State agencies) issued a draft guidance document to provide a basis for State and local governments to develop emergency plans and improve emergency preparedness for transportation accidents involving radioactive materials. The guidance document, entitled Guidance for Developing State and Local Radiological Emergency Response Plans and Preparedness for Transportation Accidents, provides optional support to State and local governments in their planning efforts.

U.S. Environmental Protection Agency

In 1970, the Presidential Reorganization Plan No. 3 established the Environmental Protection Agency (EPA). EPA has authority to establish generally applicable environmental standards for the protection of the environment from radioactive materials.

As specified in the interim Federal Radiological Emergency Response Plan issued by the FEMA, the EPA also is responsible for providing assistance to other Federal agencies, and State, Tribal, and local governments in the event of radiological emergencies (including transportation accidents involving radioactive materials). Under the interim plan, the EPA is to assist the DOE in monitoring radioactivity levels in the environment in the event of a radiological emergency, and assist (as needed) in developing recommended measures to protect public health and safety. 
Memorandum of Understanding: Transportation of Radioactive Materials

Agencies: Department of Transportation (DOT) and Nuclear Regulatory Commission (NRC)

Date of Publication: July 2, 1979 Reference: 44 Fed. Reg. 38690

Title: Transportation of Radioactive Materials; Memorandum of Understanding

Summary: The DOT is responstble for regulating safety in the transportation of all hazardous materials, while the NRC is responsible for regulating safety in recelpt, possession, and transfer of radioactive materials. This agreement delineates agency responsibilities as follows:

\& DOT: Regulates carriers of radioactive material and the conditions of transport (e.g., routing, handling and storage, vehicle requirements, and driver requirements).

\& NRC: Regulates those who possess and use radioactive material, and the design, construction, use, and maintenance of shipping containers for radioactive material exceeding certain quantity and radioactive limits (which includes containers for spent fuel and nuclear waste). In addition, the NRC enforces special transport controls (physical protection requirements) to protect against acts of sabotage. In all transportation accidents or incidents involving actual or suspected leakage of packages regulated by the NRC, the Memorandum of Understanding assigns the NRC with the responsibility to act as lead agency for investigating the cause of the leakage and preparing a report of the investigation. 
Agencies: Department of Energy (DOE) and Nuclear Regulatory Commission (NRC)

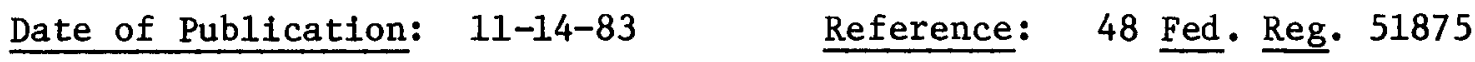

Title: Spent Fuel and High-Level Waste Transportation Packaging; NRC/DOE Procedural Agreement

Summary: Pursuant to DOT regulations [49 CFR Section 173.7(d)], the DOE has the authority to certify its packaging for radioactive materials using standards that are equivalent to NRC requirements (found at $10 \mathrm{CFR}$ Part 71 ). However, pursuant to the procedural agreement reached by the DOE and NRC in 1983, the DOE has announced its intent to use packaging approved by the NRC for DOE shipments performed under the NWPA from NRC-licensed facilities to NWPA facilities. The agreement further provides procedures for consultation and information exchange in order to resolve issues related to packaging design, testing, and certification. 


\section{DIRECTORY OF ORGANIZATIONAL CONTACTS}

I. GOVERNMENT:

\section{A. STATE:}

CONNECTICUT

GOVERNOR:

William A. 0'Ne111 (203/566-4840)

Key Contacts: State Department of Environmental Protection 165 Capitol Avenue Hartford, CT 06106

Department of Environmental Protection Marine Sciences Institute University of Connecticut Groton, CT 06340 (203/466-1020)

GEORGIA

GOVERNOR:

Joe F. Harris (404/656-1776)

Key Contacts: Department of Natural Resources 270 Washington Street, S.W. Atlanta, GA 30334

(404/656-3500)

Georgla Geologic Survey 19 Martin Luther King Jr. Drive, S.W. Atlanta, GA 30334

(404/656-3214)

\section{LOUISIANA}

GOVERNOR:

Edwin Edwards (505/342-7015)

Key Contacts: Nuclear Energy Division

Department of Natural Resources

P.0. Box 14690

Baton Rouge, LA 70898

State Planning Office

P.0. Box 44426

Baton Rouge, LA 70804

(504/342-7410) 
GOVERNOR: Joseph E. Brennan (207/289-3531)

Key Contacts: Special Assistant to the Governor

(207/289-3531)

Maine Geological Survey

State House Station 22

Augusta, ME 04333

(207/289-2801)

MARYLAND

GOVERNOR: Harry R. Hughes (301/269-3431)

Key Contact: Office of Environmental Programs 201 W. Preston Street

Baltimore, MD 21201

(301/383-2740)

MASSACHUSETTS

GOVERNOR: Michael Dukakis (617/727-3600)

Key Contacts: Executive Office of Environmental Affairs

$(617 / 727-2200)$

Radiation Control Program

150 Tremont Street

Boston, MA 02111

$(617 / 727-6214)$

\section{MICHIGAN}

GOVERNOR: James J. Blanchard (517/373-3400)

Key Contacts: Department of Transportation

State of Michigan

P.0. Box 30050

Lansing, MI 48909

(517/373-2090)

Environmental and Occupational

Health Services Administration

Department of Public Health

3500 North Logan

Lansing, MI 48909

(517/373-1578) 
MINNESOTA

GOVERNOR: Rudy Perpich (612/292-3391)

Key Contacts: Special Assistant to the Governor $(612 / 296-3391)$

Pollution Control Agency

550 Cedar Street

St. Paul, MN 55101

(612/296-9037)

Minnesota State Planning Agency

550 Cedar Street

St. Paul, MN 55101

(612/296-9037)

\section{MISSISSIPPI}

GOVERNOR:

William Allain (601/359-3150)

Key Contacts: Assistant to the Governor

New Capitol Bldg.

Jackson, MS 39205

$(601 / 359-3100)$

Special Assistant to the Attorney General Box 220

Jackson, MS 39205

$(601 / 359-3680)$

NEVADA

GOVERNOR: $\quad$ Richard H. Bryan (702/885-5670)

Key Contact: Nuclear Waste Project Office

Nevada Governor's office

Capitol Complex

Carson City, NV 89710

(702/885-3744)

NEW HAMPSHIRE

GOVERNOR: John H. Sununu (603/271-2121)

Key Contact: Office of State Planning, Environmental Aid $(603 / 271-2121)$ 
GOVERNOR :

Key Contact: Division of Environmental Quality

Department of Environmental Protection Labor \& Industry Bldg.

John Finch Plaza CN-027

Trenton, New Jersey 08625

$(609 / 292-5383$ or 2885$)$

NEW MEXICO

GOVERNOR:

Tony Anaya (505/827-3000)

Key Contact: Motor Transportation Division

New Mexico Transportation Department P.0. Box 1028

Sante Fe, New Mexico 87503

(505/827-4653)

NEW YORK

GOV ERNOR :

Mario Cuomo (518/474-8390)

Key Contacts:

New York State Department of

Environmenta1 Conservation

50 Wolf Road

Albany, NY 12233

(518/457-5915)

Bureau of Energy and Radiation

Division of Regulatory Affairs

NY State Dept. of Environmental

Conservation

50 Wolf Road

Albany, NY 12233

(518/457-5915)

NORTH CAROLINA

GOV ERNOR:

James G. Martin (919/733-5811)

Key Contacts: Department of Natural Resources and Community Development

P.0. Box 27687

Raleigh, NC 27611

(919/733-6376)

Division of Land Resources

Department of Natural Resources and Community Development

P.0. Box 27687

Raleigh, NC 27611

(919/733-3833) 
GOVERNOR:

Key Contacts:
Richard Thornburgh (717/932-0784)

Office of Policy Analysis (717/783-8002)

Bureau of Radiation Protection Department of Environmental Protection P.0. Box 2063

Harrisburg, PA 17120

(717/787-2480)

Pennsylvania Geological Survey (717/787-2169)

RHODE ISLAND

GOVERNOR:

Key Contacts: Office of Environmental Coordination Rhode Island Department of Environmental Management

83 Park Street

Providence, RI 02903

$(401 / 277-6800)$

Rhode Island Department of Administration 265 Melrose Street Providence, RI 02907 (401/277-2656)

SOUTH CAROLINA

GOVERNOR:

Richard W. Riley (803/758-3208)

Key Contacts: Special Assistant to the Governor State House

Columbia, SC 29211

$(803 / 758-7571)$

Division of Energy Policy

Governor's office

1205 Pendleton Street

Columbia, SC 29211

$(803 / 758-7571)$

\section{TENNESSEE}

GOVERNOR:

Lamar Alexander (615/741-2001)

Key Contact: Governor's Safe Growth Team

Suite 1600

James K. Polk Building

Nashville, Tennessee 37219

(615/741-5782) 
GOVERNOR: Mark White (512/475-4110)

Key Contact: Nuclear Waste Programs Office

Office of the Governor Box 12428

Austin, TX 78711

$(512 / 475-1577)$

UTAH

GOVERNOR: Norman H. Bangerter (801/533-5231)

Key Contact: Utah High Level Nuclear Waste Office 355 West North Temple

3 Triad Center, Suite 330

Salt Lake City, UT 84180-1203

$(801 / 538-5545)$

VERMONT

GOVERNOR: $\quad$ Madeline H. Kunin (802/828-3333)

Key Contacts: Agency of Environmental Conservation

State office Bldg.

Montpelier, VT 05602

(802/828-3365)

Department of Water Resources and Environmental Engineering

State Office Bldg.

Montpelier, VT 05602

$(802 / 828-3365)$

VIRGINIA

Governor: Charles Robb

(804/786-2211)

Key Contact: Virginia Solid Waste Commission

P.0. Box 3-AG

Richmond, VA 23208

(804/786-4196)

WASHINGTON

GOVERNOR: W. Booth Gardner (206/735-6780)

Key Contact: High Level Nuclear Waste Management Office

Mail Stop PV-11

01 ympia, WA 98504

$(206 / 459-6670$ or 6678$)$ 
WISCONSIN

GOVERNOR: Anthony S. Ear1 (608/266-1212)

Key Contacts: Wisconsin Radioactive Waste Review Board:

331 S. State Capito1

Madison, WI 53702

$(608 / 266-1832)$

B. REGIONAL ORGANIZATIONS

RADIOACTIVE WASTE REVIEW BOARD

921 Tenney B1dg.

110 E. Main Street

Madison, WI 53702

(608/266-0597)

NATIONAL CONFERENCE OF STATE LEGISLATURES

Energy \& National Resources

Suite 1500

112517 th Street

Denver, Colorado 80202

(303/292-6600)

SOUTHERN STATES ENERGY BOARD

Intergovernmental Programs

One Exchange Place

2300 Peachford Road

Atlanta, GA 30338

(404/455-8841)

WESTERN INTERSTATE ENERGY BOARD

3333 Quebec Street

Stapleton Plaza, Sulte 6500

Denver, CO 80207

(303/377-9459)

NATIONAL GOVERNORS' ASSOCIATION

Committee on

Energy and Environment

444 N. Capito1

Washington, DC 20001

(202/624-5372)

C. TRIBAL

YAKIMA INDIAN NATION

PO Box 151

Toppenish, WA 98948 


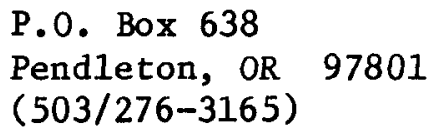

INDIAN AFFAIRS COUNCIL

127 University Avenue

St. Paul, MN 55155

(612/296-3611)

NATIONAL CONGRESS OF AMERICAN INDIANS

804 D Street, N.E.

Washington, DC 20002

(202/546-9404)

COUNCIL OF ENERGY RESOURCE TRIBES

5660 S. Syracuse Circle, Suite 206

Englewood, CO 80111

$(303 / 779-4760)$

D. DEPARTMENT

OF ENERGY

(DOE)

Ben Rusche, Director

Office of Civilian Radioactive Waste

Management

U.S. Department of Energy

Washington, DC 20585

(202/252-6850)

Roger Hilley, Associate Director for Storage and Transportation Systems Office of Civilian Radioactive Waste Management

U.S. Department of Energy

Washington, DC 20585

(202/252-2439)

Lake Barrett, Director

Transportation and Waste Systems Division

Office of Storage and Transportation Systems

U.S. Department of Energy

Washington, DC 20585

(202/252-5292)

Robert E. Philpott

Transportation and Waste Systems Division

U.S. Department of Energy

Washington, DC 20585

(202/252-9433) 
E. DEPARTMENT OF TRANSPORTATION (DOT)

Office of Regulatory Planning and Analysis, Research and Special Programs Administration 400 Seventh Street, S.W. Washington, DC 20590 (202/472-2698)

F. NUCLEAR REGULATORY

COMMISSION (NRC)

Office of Nuclear Materlal Safety and Safeguards Whillste Building

7915 Eastern Avenue

Silver Spring, MD

$(301 / 427-4063$ or 4066$)$

G. OTHER FEDERAL

AGENCIES

ENVIRONMENTAL PROTECTION AGENCY (EPA)

Standards Division Office of Radiation Programs Crystal Mall Bullding 2

1921 Jefferson Davis Highway

Arlington, VA 20460

(202/557-8610)

FEDERAL EMERGENCY

MANAGEMENT AGENCY (FEMA)

Office of Natural and Technological Hazards Program

Federal Center Plaza

500' C Street, S.W.

Washington, DC 20472

(202/287-0210)

II. BUSINESS:

AMERICAN ASSOCIATION OF RAILROADS

1920 L Street, N.W.

Suite 610

Washington, DC 20036

(202/835-9100)

ATOMIC INDUSTRIAL FORUM

7101 Wisconsin Avenue

Bethesda, MD 20814

(301/654-9260) 
2301 M Street, N.W. Washington, DC 20037 (202/775-8300)

AMERICAN NUCLEAR ENERGY COUNCIL

410 First Street, S.E. Washington, DC 20003 (202/484-2670)

AMERICAN NUCLEAR SOCIETY

555 North Kensington Avenue

La Grange Park, IL 60525

(312/352-6611)

AMERICAN TRUCKING ASSOCIATION

2201 M111 Road

Alexandria, Virginia 22314

(202/838-1700)

EDISON ELECTRIC INSTITUTE

1111 19th Street, N.W.

Washington, DC 20036

(202/828-7530)

ELECTRIC POWER RESEARCH INSTITUTE

3412 Hillview Avenue

Palo Alto, CA 94304

(415/855-2064)

ELECTRIC UTILITY COMPANIES' NUCLEAR TRANSPORTATION GROUP

P. 0. Box 270

Hartford, CT 06141

(203/655-5000).

INSTITUTE OF NUCLEAR MATERIALS MANAGEMENT

Sperry Univac Plaza

Sulte 720

8600 West Bryn Mawr Avenue

Chicago, IL 60631

(312/693-0990) 
NATIONAL ASSOCIATION OF REGULATORY UTILITY COMMISSIONERS

$$
\begin{aligned}
& \text { P.0. Box } 684 \\
& 1102 \text { ICC Building } \\
& \text { Washington, DC } 20044 \\
& (202 / 628-7324)
\end{aligned}
$$

U.S. COMMITTEE ON ENERGY AWARENESS

$$
\begin{aligned}
& \text { Bacon and Hunt } \\
& \text { Portland, Oregon } \\
& (503 / 295-2739)
\end{aligned}
$$

UTILITY NUCLEAR WASTE MANAGEMENT GROUP

$$
\begin{aligned}
& 1111 \text { 19th Street, N.W. } \\
& \text { Washington, DC 20036 } \\
& (202 / 838-7669 \text { or } 828-7534)
\end{aligned}
$$

LABOR ORGANIZATIONS:

UNITED TRANSPORTATION UNION

$$
\begin{aligned}
& 14600 \text { Detroit Avenue } \\
& \text { Cleveland, OH } 44107
\end{aligned}
$$

BROTHERHOOD OF LOCOMOTIVE ENGINEERS

$$
\begin{aligned}
& 1112 \text { BLE Building } \\
& 1365 \text { Ontario Avenue } \\
& \text { Cleveland, OH } 44114
\end{aligned}
$$

BROTHERHOOD OF MAINTENANCE OF WAY EMPLOYEES

12050 Woodward Avenue

Detroit, MI 48203

BROTHERHOOD OF RAILWAY CARMEN OF THE U.S. AND CANADA

4929 Main Street

Kansas City, MO 64112

BROTHERHOOD OF RAILWAY \& AIRLINE CLERKS

President

3 Research Plaza

Rockville, MD 20850

III. THE PUBLIC

CRITICAL MASS ENERGY PROJECT

$$
\begin{aligned}
& \text { P.0. Box } 1538 \\
& \text { Washington, DC } 20013 \\
& (202 / 546-4996)
\end{aligned}
$$


218 D Street, S.E.

Washington, DC 20003

(202/547-5330)

FRIENDS OF THE EARTH

1045 Sansome Street
San Franc1sco, CA
$(801 / 259-8493)$

LEAGUE OF WOMEN VOTERS

1730 M Street, N.W.

Washington, DC 20036

NATIONAL AUDUBON SOCIETY

950 Third Avenue

New York, NY 10022

(212/546-9300)

NATIONAL RESOURCES DEFENSE COUNCIL, INC.

1350 New York Avenue, N.W., Suite 300 Washington, DC 20005

(202/783-7800)

SIERRA CLUB

330 Pennsylvania Avenue, S.E.

Washington, DC 20003

(202/547-1141)

UNION OF CONCERNED SCIENTISTS

26 Church Street

Cambridge, MA 02238

(202/296-5600) 
FRAMEWORK FOR

TRANSPORTATION ISSUES DISCUSSION DOCUMENT (SEPTEMBER 1985)

OFFICE OF STORAGE AND TRANSPORTATION SYSTEMS OFFICE OF CIVILIAN RADIOACTIVE WASTE MANAGEMENT U.S. DEPARTMENT OF ENERGY 


\section{INTRODUCTION}

As discussed in the draft Transportation Institutional Plan, the office of Civilian Radioactive Waste Management (OCRWM) recognizes significant interest in the transportation of nuclear waste to a repository or other facilities developed under the Nuclear Waste Policy Act ${ }^{1}$ (NWPA). In an effort to foster a climate conducive to the timely identification and resolution of transportation issues, the OCRWM has initiated a dialogue with a wide range of parties having an interest in nuclear waste transportation. These interactions have led to the identification of numerous issues related to procedural, operational, and financial implications of waste transport.

To foster public participation in the review and evaluation of transport options, and assist information dissemination, the OCRWM inftiated the development of a series of transportation discussion papers on such transportation issues. To date, inftial discussion papers (on routing, prenotification emergency response, liability, overwelght trucks, inspection and enforcement, safeguard procedures, and cask design and testing) have been released for public comment.

The development of those papers represented preliminary efforts of the OCRWM to identify and discuss transportation institutional issues. To introduce a more systematic approach to the process, the OCRWM will publish a Transportation Issues Discussion Document on an annual basis; the first such document will be released in the Spring of 1986 to coincide with publication of the Transportation Institutional Plan.

This "framework" document is a precursor of the Transportation Issues Discussion Document. It reviews the intended purpose and process for development of the Transportation Issues Discussion Document, describes the format to be used for issue discussion, details the pertinent elements within each 1ssue, and offers a preliminary schedule for OCRWM policy decisions.

142 U.S.C $\$ \$ 10101-10226$. 


\section{DEVELOPMENT OF TRANSPORTATION ISSUES DISCUSSION DOCUMENT}

\subsection{Document Purpose and Planning Princlples}

The Transportation Issues Discussion Document will address specific transportation issues through "discussion papers" on each topic. Developnent of the document, which will reflect continued interaction with all interested parties, represents the practical application of the principles and proceclures detailed in the draft Transportation Institutional Plan for Identifying, addressing and working toward the resolution of transportation issues.

When evaluating NWPA transportation policy options, the OCRWM w111 consult with other Federal agencies and parties having authority or an interest in the transport of radioactive materials, and will balance varicius recommendations of interested parties with objectives for a safe, efficient, cost-effective, and publicly-acceptable NWPA transportation system. The (NCRWM also will consult with other Department of Energy (DOE) program offices in. order to ensure that NWPA transportation procedures do not adversely affect existing or future DOE procedures for radioactive materials shipments having national security implications.

\subsection{Document Content}

The Transportation Issues Discussion Document will contain discussion papers on specific transportation issues; discussion papers will include background information, a review of related issue elements, and OCRWM plans and schedules for related policy decisions. Previously issued discussion papers will be rewritten for inclusion in the document in a new, standard format and will reflect public comment, newly acquired information, and OCRWM program developments.

\subsection{Document Revision}

The OCRWM will revise and release the Transportation Issues Discussion Document on an annual basis in order to incorporate newly acquired information, program events and decisions, and public comment. Progress toward issue resolution will be noted. If an issue has been resolved, or if an OCRWM policy on an issue has been decided, the document will so note.

\subsection{Recelpt of Public Comment}

The discussion of transportation issues included in the inftial

Transportation Issues Discussion Document, to be issued in the Spring of 1.986, will reflect public comments recelved by the OCRWM (including those written in response to preliminary discussion papers, and those obtained at a

"Transportation Issue Workshop", scheduled for November, 1985).

Public comment will continue to be solicited upon the annual release of subsequent revisions of the Transportation Issues Discussion Document; a 
nine-month comment period will be set following the release of revised

documents. All comments may be addressed to:

The Office of Storage and Transportation Systems

Office of Civilian Radioactive Waste Management

U.S. Department of Energy

1000 Independence Avenue, S.W.

Washington, D.C. 20585

\subsection{Format of Discussion Papers}

Discussion papers will be prepared in a standard format having the following elements:

a) the background or overview of an 1ssue;

b) a list of associated issue elements;

c) a discussion of each issue element, including, where appropriate (and as planning continues):

- OCRWM policy options, constraints to policy decisions (such as the need for related information, or legal limits), elements of an issue that remain unresolved, and the predicted time frame for reaching an OCRWM policy decision:

- a description of the OCRWM's intended or anticipated role in the event that the OCRWM lacks authority to take a primary role in resolving an issue (e.g., the OCRWM may assume a reinforcing role by cooperating with other Federal, State, Tribal or local agencies that are responsible for making a final decision on the issue); and

- opportunities for public involvement in the evaluation of OCRWM policy options. 


\subsection{Review of Issue Elements}

The initial Transportation Issues Discussion Document, to be released in the Spring of 1986, will include discussion of the following transportation issues:

1) routing (highway);

2) prenotification;

3) emergency response/OCRWM role;

4) 1lability;

5) overweight trucks;

6) Inspection and enforcement (truck);

7) Inspection and enforcement (rail);

8) physical protection procedures;

9) cask testing programs;

10) routing (rail);

11) transportation of defense waste;

12) mixture of transport modes;

13) OCRWM training standards;

14) State, Tribal, and local regulation of transportation;

15) financial assistance/OCRWM policy;

16) procedures for interaction with States, Tribes, and local governments/OCRWM policy;

17) infrastructure improvements/OCRWM policy;

18) rail service analysis; and

19) operational procedures (safe havens, truck convoys, etc.).

The 1ssue elements that w1ll be addressed in discussion papers for each transportation issue are noted below. Each discussion paper will also include the expected timing of policy decisions related to each issue element. Initial discussion of transportation issues, and related issue elements, will be included in the first Transportation Issues Discussion Document, to be issued in the Spring of 1986. More detalled evaluation of all 188ues w111 be reflected in subsequent revisions of the document. As previously noted, the document will be revised and released on an annual basis to incorporate newly acquired information, program events and decisions, and public comment. (It again should be noted that the OCRWM seeks comment on all identified transportation issues and issue elements, and encourages the Identification of new issues and issue elements; discussion papers will be revised to reflect such comment.)

\subsubsection{Routing (highway)}

An exlsting discussion paper on highway routing (issued in November, 1984) reviews current Federal regulatory requirements. The paper will be revised on a continuing basis to include further discussion of the following Issue elements:

- the extent to which the OCRWM w111 assist States or regional organizations in highway route designation; 
- The degree of control that the OCRWM will assume in the determination of actual highway routes to be used for shipments to NWPA facilities;

- greater detail as to methods the OCRWM will use to track waste shipments;

- sanctions that may be imposed against a carrier where routing requirements are violated; and

- routing requirements that will be applied to defense waste shipments to a NWPA facility, and shipments conducted by the OCRWM for research and development activities pursuant to the NWPA.

\subsubsection{Prenotification}

An existing discussion paper (issued in November, 1984) reviews current Federal prenotification requirements for shipments of spent nuclear fuel and high-level radioactive waste. The paper will be revised on a continuing basis to include discussion of the following issue elements:

- options for the prenotification system that will be applied to commercial waste shipments to a NWPA facility;

- options for the prenotification system that will be applied to defense waste shipments to a NWPA facility;

- the prenotification system that will be applied to waste shipments for research and development activities conducted pursuant to the NWPA;

- a review of the need for, and benefits dertved from, prenotification systems; and

- viable alternatives to existing prenotification systems.

\subsubsection{Emergency Response}

An existing discussion paper (issued in November, 1984) will be revised to further review current emergency response roles of Federal agencies, States, Tribes, and local governments, and general guidance now available for emergency response planning. In addition, the paper will be revised on a continuing basis to include discussion of the following issue elements:

- the adequacy of existing emergency response capabilities (and minimum, necessary requirements);

- alternative means for meeting necessary emergency-response needs;

- Federal funding and technical assistance which are currently available for emergency response planning "and response;

- the degree to which the OCRWM will provide funding and technical assistance to States, Tribes, and local governments that will be impacted by transportation to a NWPA facility; and 
- on-going training programs.

\subsubsection{Liability}

An existing discussion paper (issued in November, 1984) reviews the current system of liability coverage for transportation accidents involving radioactive material. The paper will be revised on a continuing basis to discuss the following issue elements:

- Congressional review of, and proposed amendments to, the Price-Anderson Act;

- the amount of liability coverage deemed to be appropriate for activities related to waste transportation to a NWPA facility;

- coverage of any Federal government liability for actions related to transportation accidents;

- the effect that operation of a monitored retrievable waste facility may have on the amount and source of llability coverage;

- coverage of emergency response costs, clean-up costs, precautionary evacuations under the Price-Anderson Act; and

- 1iability coverage for acts of theft and sabotage that divert a shipment from a planned course of transportation.

\subsubsection{Overweight Trucks}

An existing discussion paper (issued in November, 1984) on the use of overweight trucks for the transport of waste to a NWPA facility will be revised on a continuing basis to review the following issue elements:

- plans to evaluate the use of larger truck shipping casks, and a description of such shipping casks;

- factors that will determine whether larger casks, and overweight trucks, will be used for waste transport to a NWPA facility;

- potential use of overweight trucks for shipments from utilities to existing rail lines; and

- state permit requirements.

\subsubsection{Safety Inspection and Enforcement (Highway)}

An existing discussion paper (issued in June, 1985) on inspection and enforcement for highway shipments of nuclear waste reviews current regulatory requirements. The paper will be revised on a continuing basis to include discussion of the following issue elements:

- the need to evaluate existing regulations against the requirements for future NWPA shipments; 
- actual enforcement of existing regulations, and the adequacy of such enforcement;

- clarification of potential State inspection roles;

- clarification of current DOT-funded State inspection and enforcement programs; and

- potential OCRWM support for regional inspection programs.

\subsubsection{Safety Inspection and Enforcement (Rail)}

An existing discussion paper (issued in June, 1985) revlewed current inspection and enforcement requirements for rail shipments of radioactive materials. The paper will be revised on a continuing basis to include further detalled discussion of:

- the need to evaluate existing regulations against the requirements for future NWPA shipments;

- State, Tribal, and local government inspection roles;

- actual enforcement of existing safety regulations, and the adequacy of such enforcement;

- the extent of carrier inspections;

- an investigation by the OCRWM of means for facilitating a cooperative effort among affected Federal and State, Tribal, and local agencies, and the rallroad industry to develop NWPA rail shipping arrangements that are safe, efficlent, and equitable, and definition of potential State, Tribal, and local government roles in such a cooperative process; and

- potential OCRWM support for regional inspection programs.

\subsubsection{Physical Protection Procedures}

An existing discussion paper (1ssued in June, 1985) on procedures (commonly called safeguard procedures) for the physical protection of shipments of radioactive materfal from acts of theft and sabotage will be revised on a continuing basis to include more detalled discussion of the following issue elements:

- physical protection procedures currently applicable to commercial and defense-related spent fuel shipments, and shipments made by the OCRWM under the NWPA for research and development purposes;

- physical protection measures that will be used for future waste shipments to NWPA facilities;

- the NRC's proposed modification of physical protection requirements; 
- State, Tribal, and local governments' concerns related to the proposed modification of physical protection procedures in relation to waste transportation to NWPA facilities; and

- the OCRWM's intended role in the debate over the appropriate level of physical protection for waste shipments to NWPA facilities.

\subsubsection{Cask Testing Programs}

An existing discussion paper (issued in June, 1985) on shipping cask design and testing will be revised on a continuing basis to include more detalled discussion of the following issue elements:

- existing standards for cask testing and licensing;

- the results of the NRC's "modal study" (which compares actual serious transportation accident conditions with cask licensing criteria);

- concerns of States, Tribes and local governments, and interest groups over the adequacy of existing standards; and

- consideration by the OCRWM of additional cask testing in order to promote public confidence in cask safety, and opportunities for interested parties to participate in the development of such a program.

\subsubsection{Rall Routing}

The OCRWM wIll prepare a discussion paper (to be updated on a continuing basis) which reviews current rail routing requirements for shipments of commercial and defense-related nuclear waste, and OCRWM shipments of nuclear waste for research and development activities conducted pursuant to the NWPA. In addition, the paper will review existing rail routing studies, and include discussion of the following issue elements:

- the potential need for, or benefits of, formal rail routing requirements, and the appropriate Federal agency to conduct such an evaluation; and

- potential rail routing procedures that may be developed for waste shipments to a NWPA facility (including discussion of the benefits or detriments of DOE-specification of actual routes to be used by carriers of waste destined for NWPA facility).

\subsubsection{Transportation of Defense Waste}

With Presidential approval of the DOE's recommendation to co-locate defense waste with commerclal waste in a single repository, DOE decisions on procedures for a transportation system for the shipment of defense waste to a NWPA facility will be necessary. A discussion paper will be prepared and updated on a continuing basis by the OCRWM to review the following issue elements: 
- the amount of defense waste that will be shipped to a NWPA facility and whether any shipments will be classified for purposes of national security;

- the transportation requirements that will be applied to defense waste shipments (including cask requirements, safeguard requirements prenotification, the possibility of real-time tracking, and routing requirements), and potential differences between the transportation procedures for defense waste and commercial waste shipments;

- the effect (if any) that an MRS facility (if approved by Congress) may have on the transport of defense waste;

- potential modes of transport, and factors that may influence decisions on transport mode selection; and

- payments to the Nuclear Waste Fund by the DOE's Office of Defense Programs for the transportation of defense high-level waste to NWPA facilities.

\subsubsection{Mixture of Transport Modes}

Modes of transport for waste shipments to NWPA facilities may involve ra11, truck, and barge. A discussion paper will be developed and updated on a continuing basis by the OCRWM to review the following issue elements:

- potential barge transport and related OCRWM studies;

- criteria to be used for selecting appropriate modes of transport, including the effect of operating an MRS facility (if approved by Congress) on selection of transport modes; and

- Identification and evaluation of the necessary interfaces between different transport modes.

\subsubsection{Training}

The OCRWM will develop a discussion paper (to be updated on a continuing basis) which reviews current training requirements and/or programs for carriers of radioactive materials, and emergency response personnel. In addition, the paper will contain discussion of the following related issue elements:

- concerns of States, Tribes and local governments that Federal1y certified programs of driver training may be necessary to promote transportation safety and greater public confidence in such safety;

- OCRWM options for requiring standard training programs for carriers of waste destined for NWPA facilities;

- options for future financial and technical assistance for emergency response planning and training activities of States, Tribes, and local governments that may be impacted by waste transportation to NWPA facilities; and 
- the need to assure consistent levels of training and emergency response capabilities for State, Tribal and local emergency

responders who may be impacted by waste transportation to NWPA facilities.

\subsubsection{State, Tribal, and Local Regulation of Transportation}

The OCRWM will develop a discussion paper (to be updated on a continuing basis) which contains a general review of the relationship between Federal and State law, and application of the Federal preemption doctrine where State laws are found to be inconsistent with the terms or purpose of Federal regulation of certain activities. In addition, the paper will address the following related topics:

- current DOT and court guldelines used to determine regulatory inconsistency in terms of transporting radioactive materials;

- procedures avallable for resolving regulatory inconsistency (DOT advisory rulings and court decisions), including estimated lengths of time that various issue-resolution procedures may take;

- recent DOT advisory rulings and court decisions affecting the transportation of nuclear materials; and

- OCRWM policy options for addressing State, Tribal, and local transport restrictions that may affect waste transport to NWPA facilities; and

- purposes of fee and permit system, and potential alternatives to such measures.

\subsubsection{Financial Assistance/OCRWM Policy}

The OCRWM will develop a discussion paper (to be updated on a continuing basis) which reviews current grant procedures under the NWPA for the conduct of site-specific program activities, including those related to transportation, and OCRWM guidelines that are now being developed to specify the availability and appropriate use of such financial assistance. In addition, the paper will contain discussion of:

- possible financial assistance in the form of contracts for studying regional or specific transportation issues; and

- options for financial assistance to non-host States, Tribes (other than those defined as "affected" under the NWPA), local governments, and representative or technical organizations for such activities as emergency response training, inspection and enforcement activities, infrastructure improvements, and routing analyses.

3.1.16 Procedures for Interaction with States, Tribes, and Local Governments/OCRWM Policy

The OCRWM wIII prepare a discussion paper (to be updated on a continuing basis) on options for Interacting with States, Tribes, and local governments 
which, although not directly affected by NWPA siting activities, may be impacted by waste transportation to NWPA facilities. Such interaction could

- be structured to address many of the same transportation issues that are to be covered in written agreements with "affected" States and Tribes under Section $117(\mathrm{c})$ of the NWPA, including:

- questions of 1lability for accidents;

- ongolng emergency preparedness and emergency response activities;

- monitoring nuclear waste transportation; and

- notification prior to nuclear waste shipments through various jurisdictional boundaries.

\subsubsection{Infrastructure Improvements/OCRWM Policy}

A discussion paper will be prepared (and updated on a continuing basis) by the OCRWM to review those issues related to infrastructure improvements (such as upgraded road and rail-beds, and bridge repairs or improvements) that may be necessary to support waste transportation to NWPA facilities. Such issues include:

- mechanisms for evaluating necessary infrastructure improvements; and

- OCRWM options for addressing the infrastructure needs of States and Tribes (other than "affected" States, and Tribes as defined in the NWPA) impacted by NWPA transportation, including a determination of appropriate responsibilities and funding sources.

\subsubsection{Rail Service Analysis}

The OCRWM will prepare a discussion paper (to be updated on a continuing basis) which reviews various options for rail service, and studies that have been prepared on such service. The paper will indicate the OCRWM's current position on the use of "dedicated special train service" (service for carrying nuclear material in which no other cargo is carried, travel speeds are restricted, buffer cars are used, and when a "special train" is passed by another train, one train must come to a complete stop), and "unit" (also referred to as "dedicated") train service (that service where only one cargo is carried, no intermediate stops are made at marshalling yards for additional cargo-loading, and the train travels at normal speeds). In addition, the paper will review the following issue elements:

- the need to further evaluate the costs and benefits of potential rail transport using different rail service; and

- OCRWM options for rail service in the transport of spent fuel and high-level radioactive waste to NWPA facilities.

\subsubsection{Operational Procedures}

The OCRWM recognizes continued public interest in the evaluation and potential implementation of operating procedures which would supplement 
current requirements for the transportation of radioactive materials. In response to such interest, the OCRWM will prepare a discussion paper (to be updated on a continuing basis) which identifies such operational concerns, and reviews OCRWM implementation options. The paper will include discussion of the following operational issues (and, where appropriate, those agencies having potential implementation responsibilities):

- potential development and use of "safe havens" along major transport routes;

- the request of some interested parties for the evaluation of potential use of different identification numbers for new and spent nuclear fuel, and/or color-coded casks for shipments of radioactive materials, in order to assist emergency response personnel in their determination of appropriate actions in accident situations where shipping papers or other means of identifying a cargo are not available;

- potential imposition of stricter limitations on stopping times of nuclear waste shipments destined for NWPA facilities;

- potential uniform requirements for on-board communication equipment and radiation-detecting equipment;

- possible use of truck "convoys" for NWPA shipments;

- possible required use of cabooses for rail shipments to NWPA facilities; and

- methods for, and associated costs of, limiting radiation doses to levels which are "as low as reasonably achievable" (also referred to as the ALARA concept), and application of the ALARA concept to transportation activities conducted pursuant to the NWPA.

\subsection{Timing of Policy Decisions for Major Transportation Issues}

The OCRWM has developed an initial schedule for making final policy decision on each major category of transportation institutional issues. The schedule was determined with reference to OCRWM program milestones identified in the Mission Plan and draft Transportation Business Plan, and is detalled in Figure 1. A more comprehensive discussion, and the expected timing of policy decisions on all elements of each major transportation issue (listed in the preceding section), will be included with every "discussion paper."

The preliminary schedule for making final policy decisions on each major category of transportation issues must be viewed in light of three important factors:

1. The decision schedule represents the latest time at which policies for all elements of an issue must be decided by the OCRWM; many elements of each major transportation issue will be addressed, and an OCRWM policy decision reached, before that time. 


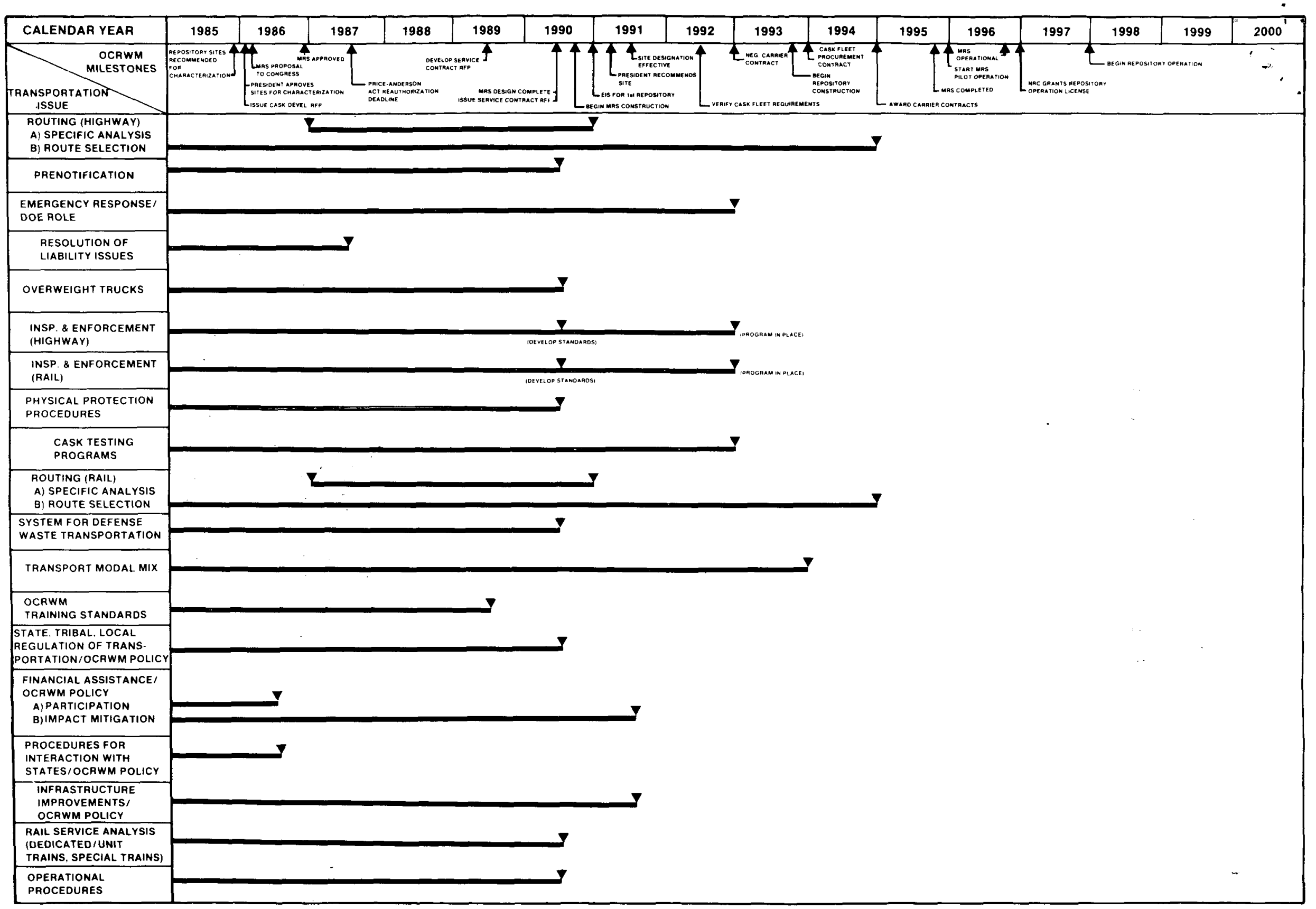

Figure 1. Preliminary schedule for transportation policy decisions 
2. The decision schedule is based on the assumption that all events " related to the waste management program proceed on an ideal schedule," and does not recognize potential delays. Should activities related to the waste management program be delayed, timing assumptions contained in the Transportation Issues Discussion Document will be adjusted accordingly.

3. The decision schedule reflects the assumption that a monitored retrievable storage facility will be developed, although Congressional approval of the facility will be required. Such an assumption was made in order to a account for related transportation institutional issues.

A description of timing goals for policy decisions related to each major transportation issue follows.

\subsubsection{Routing (Highway and Rail)}

The timing of decisions related to the routing of waste transport by highway and rail will be affected by two major OCRWM activities: 1) route-specific evaluations of the potential cost and risk of nuclear waste transport to NWPA facility; and 2) evaluations of the appropriate degree of control that OCRWM should exercise in the determination of the actual routes used by carriers for shipments to a NWPA facility.

Route-specific evaluations of potential transport cost and risk will be conducted by the OCRWM during the development of the environmental impact statement for the three sites selected for characterization studies; such activity is expected to begin in late 1986, and to be completed in late 1990. Factors that the OCRWM will examine in route-specific evaluations will be determined in consultation with the interested public. Comment will be solicited at a transportation workshop scheduled for November, 1985, and at a routing workshop projected for fiscal year 1986.

The decision of the appropriate degree of control that the OCRWM should assume in selecting actual routes (consistent with DOT routing regulations) to be used for shipments to NWPA facilities will be made by 1995 . At that time, negotiations for carrier contracts are expected to be nearing completion.

\subsubsection{Prenotification}

By mid-1990, the OCRWM expects to complete ongoing evaluations of potential notification systems and specify required procedures (including the possible use of real-time tracking, and the notification system to be used for defense waste shipments) for prenotifying States through which nuclear waste will be transported to NWPA facilities. While the OCRWM has stated its intent to follow all NRC nuclear waste transportation requirements (which may include prenotification) that exist when shipments of commercial waste are made to NWPA facilities, feasible alternatives to current prenotification procedures could be employed. The timing of such a policy decision is related to the 
necessary information that will be required to support a potential OCRWM réquest for proposals in 1990 for private companies to act as service contractors for transport operations. 2

A decision has been made by the OCRWM to apply existing DOE notification procedures to current ongoing shipments of nuclear waste for "research and development" activities conducted pursuant to Section 218 of the NWPA. Such notification procedures were approved by the DOT as part of a "physical protection system" required by DOT regulations [at 49 CFR Section 173.22(c)], and include the periodic provision of generic shipping information to appropriate State or officials (or local law enforcement agencies, where jurisdictional needs requires) concerning the nature of DOE shipments, and emergency response procedures and contact points. In addition, the OCRWM provided supplemental communication to the heads of radiological health programs in States through which nuclear waste shipments for "research and development" activities will travel; the communication included a general description of the type and number of shipments, but not the designated dates and times of shipment. The OCRWM considers such supplemental notification of "research and development" shipments to be an initial step in the development of formal notification procedures for future transportation to NWPA facilities.

\subsubsection{Emergency Response}

The OCRWM is committed to working with the FEMA, the States, and Indian tribal governments to review the adequacy of existing emergency response capabilities, needs for financial and technical assistance, and alternative means for meeting necessary emergency response requirements. A policy decision which defines the appropriate role of the OCRWM in the development of a comprehensive emergency response program for NWPA shipments is expected to be made by 1993 ( 18 months after a site for the first repository is selected).

\subsubsection{Transportation Liability Issues}

The Price-Anderson Act (42 U.S.C. Sections 2014 and 2210, as amended) currently provides extensive public liability coverage in the event of a serious accident involving the transportation of nuclear materials to or from certain Federally-licensed or Federal contractor-operated facilities. Congressional review of the Federal public liability system is to be completed by 1987, when the Act will expire unless reauthorized. The Department of Energy and the OCRWM have participated in Congressional deliberations of the Act and proposed amendments, and offered the DOE's position related to the Act's applicability to activities conducted pursuant to the NWPA, including

2 The OCRWM is now investigating the use of service contractors who would be responsible for: assembling a transport fleet; making carriage arrangements; providing inspection, maintenance, and repair services; the training of security and operations personnel; and managing transportation operations. If the option of using service contractors is found to be efficient and cost-effective, two or more service contractors would be selected by competitive bidding. 
the transportation of spent fuel and high-level radioactive waste to NWPA facilities. The OCRWM will continue to examine liability issues related to "i NWPA activities, and anticipates that major issues will be resolved by the deadline for reauthorization of the Price-Anderson Act.

\subsubsection{Overweight Trucks}

Analyses related to the impacts associated with, and potential use of, overweight trucks (due to the use of large shipping casks) for spent-fuel transport to NWPA facilities are now being conducted by the OCRWM. Whether the use of such casks offers a viable means of spent-fuel transport to a NWPA facility is expected to the determined by mid-1990, when the OCRWM will issue a request for proposals for service contracts.

\subsubsection{Inspection and Enforcement (Highway and Rail)}

Planning and preparations for waste transportation to NWPA facilities will include the development of OCRWM inspection procedures and an inspection program which defines appropriate inspection and enforcement roles of the OCRWM, its contractors, and States. The development of inspection standards is expected to be complete by $\mathrm{mid}-1990$, and is associated with the issuance of a request for proposals for service contracts. As previously noted, the OCRWM will thoroughly investigate the use of full service contractors for proposed transportation operations. If the option of using service contractors is shown to be efficient and cost-effective, the OCRWM will select at least two service contractors on a competitive basis; the OCRWM would then develop inspection and periodic compliance testing procedures that service contractors would be required to adhere to and execute in order to comply with appropriate regulatory standards.

A comprehensive inspection and enforcement program (including inspection standards and procedures, training requirements, and definitions of cooperative Federal and State inspection activities and mechanisms of enforcement) necessary to support NWPA transportation is expected to be in place by 1993, at which time the OCRWM or service contractors are scheduled to begin negotiations for carrier contracts.

\subsubsection{Physical Protection Procedures}

The OCRWM has stated its intent to comply with all NRC nuclear waste transportation requirements in effect at the time of shipments of commercial nuclear waste to NWPA facilities. An OCRWM decision on all physical protection procedures for NWPA transport is expected to be made by mid-1990, when a request for proposals for service contracts will be issued.

\subsubsection{Cask-Testing Programs}

In a procedural agreement with the NRC, the DOE announced its intent to use casks certified by the NRC for DOE nuclear waste shipments performed under the NWPA from NRC-1icensed facilities to a repository, monttored retrievable storage facility, or interim storage facility ( 48 Fed. Reg. 51875). The OCRWM will continue to address cask-certification issues and consult with the NRC on studies related to transportation accident conditions and the adequacy of current cask-design criteria. An OCRWM prototype cask-testing program is 
expected to be developed by 1992. Such timing is related to verification by OCRWM of cask fleet requirements by mid-1992; testing of cask prototypes will begin by 1993 .

\subsubsection{Defense Waste Transportation}

On April 30, 1985, the President directed the DOE to proceed with arrangements to co-locate defense high-level radioactive waste with commerclal nuclear waste in a geologic repository. The OCRWM is therefore participating in discussions with the DOE's Office of Defense Programs (which currently manages defense high-level waste transportation) to determine the appropriate system for shipping commercial and defense-related nuclear waste to a repository. The OCRWM anticipates that all elements of such a system (including cask requirements, safeguard requirements, routing procedures, and notification to States through which shipments will trave1) will be determined by mid-1990, when the OCRWM plans to issue a request for proposals for service contracts. The OCRWM expects that a disposal contract for defense waste, and an appropriate scale of contributions to the Nuclear Waste Fund, will be developed well before 1990 .

\subsubsection{Transport Modal Mix}

Modes of transport to a NWPA facility may involve train, truck, and barge. While studies of potential modes of transportation and associated transportation impacts are currently under way, the OCRWM anticipates that a final decision on the modal mix for transport to a NWPA facillty will not be made until the end of 1993, at which time contracts for the development of a cask fleet will be awarded.

\subsubsection{OCRWM Training Standards}

The OCRWM has begun to evaluate current training requirements and the development of training standards needed to support various activities related to waste transportation to NWPA facilities. Training standards will be consistent with NRC and DOT requirements, contribute to operational safety, and be designed to reinforce public confidence in the overall transportation system. Under current program schedule assumptions, the OCRWM will develop training standards for cask maintenance and servicing, driver instruction, emergency response procedures, and inspection and security activities by mid-1989. Such timing directly corresponds with the OCRWM's development of a request for proposals for service contracts.

\subsubsection{State, Tribal, and Local Regulation of Transportation}

By mid-1990, the OCRWM expects to issue a written policy statement of agency plans to address State and local transport requirements and restrictions that may affect the transport of nuclear waste to NWPA facilities. The OCRWM policy will rely on DOT advisory rulings ("Inconsistency Rulings" and "Non-Preemption Determinations) and court decisions related to the validity of such transport requirements and restrictions. The issuance of a policy statement is intended to assist States, Tribes, and local governments in timely planning for waste transportation to NWPA facilities, and to advise potential bidders on service and carrier contracts of the various transport requirements that must be 
considered and incorporated into contract proposals. The timing of the polify decision is related to the anticipated issuance of a request for proposals fo: service contracts.

\subsubsection{Financial Assistance/OCRWM Policy}

The OCRWM is now evaluating financial assistance procedures and preparing written policy guidelines which will detail financial assistance provided under the NWPA for participation in site-specific program activities, including those related to transportation. In addition, the OCRWM plans to facilitate participation in transportation program planning through a system of contractual relationships with governmental bodies and professional and technical organizations. Policy guidelines related to the provision of such financlal assistance are expected to be issued in mid-1986.

As authorized by the NWPA, following selection of facllity sites, the OCRWM will provide assistance to host States, affected Tribes, and local governments as necessary to mitigate impacts associated with the construction and/or operation of a repository or MRS facility (if approved by Congress). Upon final site selection, the OCRWM, in consultation with such States, Tribes, and local governments, will determine what financial assistance is needed and legally allowable to mitigate potential transportation impacts. In addition to providing assistance to the affected governmental bodies, OCRWM will also evaluate the potential need for, and appropriate uses of, assistance to non-host States and governmental bodies that may be impacted by NWPA transportation. The OCRWM expects that such a determination will be made by mid-1991, when a site is designated for the development of the first repository.

\subsubsection{Procedures for Interaction with States, Tribes, and Local Governments}

The NWPA (Section 117) provides for the development of written "consultation and cooperation agreements" between the DOE and potential host States and affected Indian Tribes (or those States identified as having potentially acceptable repository sites or having sites approved for characterization, and Tribes having lands or rights which may be affected by repository siting, development, and operation). The OCRWM is now reviewing potential means of interacting with other States, Tribes, and localities that may be Impacted by the transport of nuclear waste to a NWPA facility; a written statement of such a policy position will be issued in mid-1986.

\subsubsection{Infrastructure Improvements/OCRWM Policy}

During the 1986 fiscal year, the OCRWM plans to evaluate the infrastructure capabilities of a typical reactor site in order to determine what improvements in the vicinity of the site may be necessary to support waste transport to a NWPA facility.

The OCRWM plans to complete further evaluations of the need for other specific infrastructure improvements (including road and rail-bed upgrading, and bridge improvements) necessary to support NWPA transportation, Federal and State responsibilities for making such improvements, and appropriate funding sources by the time the DOE nominates a site for the first repository. Under current timing projections, the OCRWM expects to issue a related policy statement by early 1991. 